OPEN ACCESS

Review-Non-Carbonaceous Materials as Cathodes for Lithium-Sulfur Batteries

To cite this article: Analía N. Arias et al 2018 J. Electrochem. Soc. 165 A6119

View the article online for updates and enhancements. 


\title{
Review-Non-Carbonaceous Materials as Cathodes for Lithium-Sulfur Batteries
}

\author{
Analía N. Arias, Alvaro Y. Tesio, and Victoria Flexer (ํ) ${ }^{\mathrm{z}}$ \\ Centro de Investigación y Desarrollo en Materiales Avanzados y Almacenamiento de Energía de Jujuy-CIDMEJu \\ (CONICET-Universidad Nacional de Jujuy), Centro de Desarrollo Tecnológico General Savio, Palpalá, Jujuy 4612, \\ Argentina
}

\begin{abstract}
Lithium-sulfur batteries are presented as a promising alternative for the operation of those devices, including electric vehicles, that require higher specific capacity than current lithium-ion technology. Unfortunately, lithium-sulfur batteries suffer from several limitations that still produce a relatively fast capacity fading and poor utilization of active materials. In order to alleviate the disadvantages that arise at the cathode, several researchers have searched for new electrode materials. Because of the long standing tradition in the use of carbons in energy storage systems, carbonaceous cathodes have been the most popular choice. Recently, however, there has been a trend for the study of non-carbonaceous materials as cathodes in lithium-sulfur systems. Materials such as polymers, metal oxides, metal carbides, amongst many others were reported, showing excellent properties which make them compete side by side with state of the art carbonaceous cathodes. These materials have generally improved the conductivity of the conventional sulfur electrode, and have provided a 3D soft adsorbent porous structure, which efficiently traps polysulfides. These characteristics are reflected in an improved electrochemical performance, reaching, in some cases, capacity retention values close to $1000 \mathrm{~mA} \mathrm{~h} \mathrm{~g}^{-1}$ after 100 cycles at high discharge rate. Here, we propose a review of these non-carbonaceous cathodes.

(C) The Author(s) 2018. Published by ECS. This is an open access article distributed under the terms of the Creative Commons Attribution 4.0 License (CC BY, http://creativecommons.org/licenses/by/4.0/), which permits unrestricted reuse of the work in any medium, provided the original work is properly cited. [DOI: 10.1149/2.0181801jes]

(cc) BY
\end{abstract}

Manuscript submitted November 28, 2017; revised manuscript received January 7, 2018. Published January 18, 2018. This paper is part of the JES Focus Issue on Lithium-Sulfur Batteries: Materials, Mechanisms, Modeling, and Applications.

The specific energy of current lithium-ion secondary batteries is very close to reaching its theoretical thermodynamic limit. ${ }^{1}$ This specific energy value is limited for some technological applications, such as long autonomy range electric vehicles. ${ }^{2}$ Although no other rechargeable battery technology has shown the fantastic cyclability and stability of lithium-ion batteries, the search for new rechargeable battery technologies is a very active field of research.

Lithium-sulfur (Li-S) batteries are one of several alternative systems that have been proposed for higher specific energy density rechargeable batteries. A lithium-sulfur battery consists of a lithium anode, an organic electrolyte and a sulfur composite cathode..$^{2-5}$ During the discharge process, at the anode, metallic lithium is oxidized to lithium cations $\left(\mathrm{Li}^{+}\right)$, while at the cathode, and in the presence of lithium ions, elemental sulfur is reduced to lithium sulfide $\left(\mathrm{Li}_{2} \mathrm{~S}\right)$. These batteries are presented as a promising alternative energy storage system, since they are relatively light and they have the advantage of a high theoretical energy density of $2600 \mathrm{Wh} \mathrm{kg}^{-1}$, which is almost 6 times higher than that of commercial lithium-ion batteries $(387 \mathrm{Wh}$ $\mathrm{kg}^{-1}$ for $\mathrm{LiCoO}_{2}$-graphite battery). ${ }^{6}$ In addition, sulfur has a very low cost and is largely abundant in nature. ${ }^{7-9}$ The foundational stone on lithium-sulfur cells was led in 1962 by Herbert and Ulam, who proposed the use of elemental sulfur as cathode material. ${ }^{10}$

Despite their numerous theoretical advantages, lithium sulfur cells are still not commercially available due to a series of limitations. ${ }^{11}$ Several issues produce a low utilization of the active materials, which overall result in a low cyclability. During the discharge process, sulfur is not directly reduced to $\mathrm{Li}_{2} \mathrm{~S}$ but forms firstly high-order polysulfide species, with formula $\mathrm{Li}_{2} \mathrm{~S}_{\mathrm{x}}(4<\mathrm{x}<8)$. Then, continuing the reduction process, the low-order polysulfides, $\mathrm{Li}_{2} \mathrm{~S}_{2}$ and $\mathrm{Li}_{2} \mathrm{~S}$ both insoluble are formed. ${ }^{12}$ The high-order polysulfides are highly soluble in commonly used organic electrolytes; their dissolution and subsequent diffusion from cathode to anode gives rise to the so called shuttle effect, i.e. the loss of active cathode material in the electrolyte, and the direct oxidation of metallic lithium by these polysulfides that still have reducing capacity. ${ }^{13}$ The shuttle effect generates low coulombic efficiency. ${ }^{14,15}$ The non-uniform deposition and dissolution of lithium (charge and discharge respectively) leads to the formation of den-

${ }^{\text {zE} E-m a i l: ~ v f l e x e r @ u n j u . e d u . a r ~}$ drites on the surface of the lithium metal anode, presenting a high reactivity. The formation of dendrites is due to the instability of the passivation layer which decreases the cycling efficiency of lithium. ${ }^{16}$ In addition, the soluble polysulfides can give rise to parasitic reactions affecting even more the conservation of a stable passivation layer. ${ }^{17,18}$ Associated to the shuttle effect, another problem with the performance of lithium-sulfur batteries is the issue of self-discharge. This self-discharge process is associated with the migration of cathode active materials toward the lithium anode in the form of either dissolved sulfur molecules (fresh cell) or soluble polysulfides that come from the electrochemical reduction of sulfur during cell cycling. Once again, as a consequence of the loss of the active material in the cathode, the capacity of the battery decreases. Cathode materials, membranes and also cell configurations can all play a fundamental role to solve this problem. Unfortunately, very few articles in the literature report how the studied materials behave against this phenomenon and it is often difficult to make an exhaustive comparison between them.

Moreover, related to the self-discharge issue, there is another difference between carbonaceous and non-carbonaceous materials. This fact lies in the following process: a small fraction of solid sulfur might dissolve upon coming in contact with the electrolyte. This dissolved sulfur, even though being retained in the cathode structure, can be reduced without a passage of net current in the cell, i.e. direct reduction by the cathode material itself, which in turn is oxidized, and not by the electrons delivered via the external electrical circuit. The probability that this reaction takes place depends mainly on the nature of the cathode material. Carbonaceous materials are, in general, more reducers than most non-carbonaceous ones, e.g. polymers and metal oxides. Therefore, it is clear that non-carbonaceous materials have an inherent advantage, in terms of solving this problem of self-discharge in lithium/sulfur batteries.

Furthermore, the electrically insulating nature of both elemental sulfur and $\mathrm{Li}_{2} \mathrm{~S}$ create non-minor issues. Finally, important volume changes during the charge and discharge processes are observed. At the cathode, a volume expansion as high as $80 \%$ during discharge and a volume contraction upon charge is observed, ${ }^{19}$ while the volume is contracted upon discharge at the anode. ${ }^{20}$

Since the original seminal reports, many researches have worked on the development of new electrode materials, ${ }^{21}$ electrolytes with 
higher efficiencies ${ }^{22,23}$ and novel cell configurations, ${ }^{16}$ with the aim of overcoming the above mentioned limitations and achieving higher cyclability of the lithium-sulfur cells. Although the disadvantages are presented in the different components of the battery, much bigger efforts have been dedicated to the cathode. The insulating nature of elemental sulfur, leads to the need to incorporate conductive and/or support materials, which function as host material for the sulfur particles. ${ }^{19,24}$ These agents are added not only to enhance the conductivity. Many compounds can also improve the electrochemical results because they aid by some other mechanisms to a more efficient utilization of the active cathode material. The terminology binary composite refers to those cathode materials where the sulfur particles are incorporated, by any synthesis method, into a host material structure, for example graphite, porous carbonaceous materials, polymers or metal oxides. $^{25}$ By analogy, ternary composites are those that result from combining elemental sulfur with two different types of host materials such as polymers and metal oxides acting mainly as conductive and adsorbent material respectively. ${ }^{26}$

Most researchers have focused on the search of materials based on carbonaceous structures, ${ }^{27}$ such as microporous carbon, ${ }^{28}$ mesoporous carbon, ${ }^{28}$ carbon nanotubes,${ }^{29}$ carbon nanofibers, ${ }^{30}$ porous carbon spheres, ${ }^{31}$ and graphene. ${ }^{32,33}$ Due to their physical and chemical properties, ${ }^{34}$ porous structures and high electrical conductivity, in addition to its relative low cost and large abundance, it is not surprising that good results and important advancements in the field have been obtained with carbonaceous electrodes. ${ }^{35,36}$ However, capacity loss remains one of the main drawbacks to be solved. In carbonaceous electrodes, without any structural modification, the interaction between sulfur compounds and $\mathrm{C}$ is only physical. This weak interaction leads to the escape of species from the structure (shuttle effect) of the material causing capacity loss. ${ }^{37}$ The possibility to incorporate polar functional groups to pristine carbonaceous structures to enhance the surface polarity has been proposed. ${ }^{38,39}$ Thus, the electrical conductivity is improved and the dissolution of polysulfides is decreased.

Despite the enormous popularity of carbonaceous materials, other host materials such as polymers, metal oxides, and nitrides, have been proposed as candidates for cathode materials in lithium-sulfur cathodes and most interesting results have been reported. ${ }^{11,12}$ To the best of our knowledge, this important field has not yet been reviewed or critically analyzed as a whole, except for two reviews on polymeric compounds only ${ }^{12,40}$ and a recent review on nanostructured metal oxides and sulfides. ${ }^{41}$ In the present review, we wish to present and discuss the performance of those non-carbonaceous materials, making a special emphasis on publications in the field from the last eight years.

One of the main advantages of polymeric materials, is that, unlike carbons, they offer soft structures which accommodate well the volume changes that take place during the operation of the battery. Moreover, a stronger interaction between the polymer and the different sulfur composites takes place, because of the presence of specific functional groups in the polymeric structure. ${ }^{12,40}$ Although polymers were originally thought as more likely materials to be incorporated into cathodes, with respect to metal oxides, a tendency to the study and exploration of the latter has been recently observed. Later on, the synthesis of hybrid composite materials, where both polymer and metal oxides are used, has been reported. Finally, most recently, the possibility to use a large variety of both organic and inorganic compounds, that can be neither classified as polymers, nor as metal oxides have been put forward.

With regards to polymers, we have only considered materials where the polymer does not undergo a carbonization process. Otherwise, we consider the said material should no longer be considered a polymer, but a carbon. Furthermore, in many reports binary/ternary novel materials are mixed with both conductive and binder agents. Because conducting agents are most often carbons (ketjenblack, vulcan, and the like), we have also decided that in order to classify a novel cathode in the non-carbonaceous category, not more than a $20 \mathrm{wt} \%$ of conductive agent should be added to the preparation of the positive electrode.

\section{Sulfur-Polymer Composite Cathode Materials}

Most often, the sulfur-polymer structures can generate a conductive matrix that favors the transport of both ions and electrons during the operation of the cell. When polymers are used as host materials in sulfur cathodes, a soft structure is created that allows to accommodate the volume changes undergone by the cathode during the charge and discharge processes. In addition, a stronger interaction of both physical and chemical nature is established between the polymeric material and both elemental sulfur and polysulfides, which is in marked contrast to the much weaker interactions stablished by most carbonaceous compounds. A large variety of polymers has been proposed as host materials for sulfur, including polypyrrole (PPy), polyaniline (PANI), polythiophene (PTh), polyacrylonitrile (PAN), sulfur enriched commercial rubbers and vegetable oils.

Table I gathers the most important data of articles reporting the use of polymers in sulfur cathodes published since 2010. In some examples, it is necessary to add a conductive agent such as Super P carbon, acetylene black, or ketjenblack. ${ }^{42-45}$ In other cases, the use of the composite material only was enough to prepare the cathode. ${ }^{46}$

Synthesis of S-polypyrrole composite materials encompasses methods involving in situ polymerization, ${ }^{47-49}$ as well as methods where first polymerization is carried out, followed by encapsulation of elemental sulfur particles. ${ }^{50,51}$ Materials have been obtained with a sulfur content that covers a wide range of values, from $50 \mathrm{wt} \%$ and up to $80 \mathrm{wt} \%$ sulfur content (see Table I).

Different structures for the composite materials have been reported, including core-shell structures, ${ }^{47,48}$ branched structures,${ }^{50}$ and others where orthorhombic bipyramidal sulfur particles can be coated in situ by a layer of stacked conductive polypyrrole nanospheres. ${ }^{42}$ In coreshell structures, an elemental sulfur particle is usually at the core, and the conducting polymer is the shell. The enhanced electrochemical performance shows that the PPy nanolayer coating contributes to an effective electron conduction path and a strong physical and chemical confinement of polysulfides. ${ }^{47,48,52}$ Conversely, in branched structures the sulfur particles are homogenously distributed over the highly branched PPy nanowires. ${ }^{50}$ This homogeneous distribution of sulfur enhances its contact with the conductive polymer, leading to an improvement in sulfur utilization. The porous branched nanostructure with high surface and absorbing ability allows to accommodate the volume changes of the composite and the absorption of polysulfides into the pores during the charge and discharge processes. These properties improve the electrochemical performance and cyclability of the cathode. ${ }^{50}$ In the composite cathode material synthetized by Manthiram's group, the orthorhombic bipyramidal sulfur is coated by a conductive polypyrrole nanolayer, which is formed by a stack of polypyrrole nanospheres. This structure facilitates efficient transport of electrons and decreases the loss of active materials and the shuttle effect. $^{42}$

The best results for a PPy based material were reported by Chen et al., ${ }^{48}$ who synthesized polypyrrole-coated sulfur (PPy@S) with a core-shell structure via in situ polymerization of pyrrole monomers on the surface of sulfur nanoparticles using ferric chloride as an oxidizing agent. The synthesis process consisted of the following stages: mixing reagents in aqueous media followed by sonication at room temperature for $2.5 \mathrm{~h}$, filtering, washing with water and methanol and vacuum-drying. For the electrochemical assays, the composite cathode was prepared by mixing 80 wt $\%$ PPy@ S composite, 10 wt $\%$ polyvinylidene fluoride $(\mathrm{PVdF})$ as binder and $10 \mathrm{wt} \%$ acetylene black as conductive agent. An initial discharge capacity of $1200 \mathrm{~mA} \mathrm{~h} \mathrm{~g}^{-1}$ at $0.2 \mathrm{C}$ was obtained. Capacity retention of $913 \mathrm{~mA} \mathrm{~h} \mathrm{~g}^{-1}$ at 0.2 $\mathrm{C}$ after 50 cycles was achieved. Previously, the same group had proposed a material with similar characteristics, but with a branched structure. It was synthesized in two stages. The first stage involving the polymerization of the pyrrole monomer at $0-5^{\circ} \mathrm{C}$ for $24 \mathrm{~h}$, using ammonium persulfate as oxidizing agent. And secondly, incorporating sulfur in the structure by a simple ball milling at 600 RPM for $3 \mathrm{~h}$. In that original work, the results were less favorable achieving a discharge capacity of $500 \mathrm{~mA} \mathrm{~h} \mathrm{~g}^{-1}$ at a low current density, 


\begin{tabular}{|c|c|c|c|c|c|c|c|}
\hline Composite & {$[\operatorname{Ref}]$} & Morphology & Synthesis method & $\begin{array}{l}\text { Current } \\
\text { rate/density } \\
{[C]}\end{array}$ & $\begin{array}{c}\text { Capacity } \\
\text { retention } \\
{\left[\mathrm{mA} \mathrm{h} \mathrm{g}^{-1}\right]} \\
\left(\mathrm{n}^{\circ} \text { cycles }\right)\end{array}$ & $\begin{array}{l}\text { Sulfur } \\
\text { content } \\
{[\text { wt } \%]}\end{array}$ & Cathode composition [wt $\%$ ] \\
\hline \multirow[t]{7}{*}{ Polypyrrole-sulfur } & 47 & core-shell & S/PPy via in situ oxidative polymerization. & 0.1 & $613(50)$ & 61.9 & composite:AB:PVdF (80:10:10) \\
\hline & 49 & core-shell & S@PPy via in situ polymerization. & 0.1 & $\sim 750(100)$ & 80 & composite:AB:PVdF (80:10:10) \\
\hline & 48 & core-shell & PPy@S vi in situ oxidative polymerization. & 0.2 & $913(50)$ & NR & composite:AB:PVdF (80:10:10) \\
\hline & 50 & branched-like nanowires & $\begin{array}{l}\text { PPy by an oxidative polymerization. The S-PPy } \\
\text { composite by ball milling. }\end{array}$ & $100 \mathrm{~mA} \mathrm{~g}^{-1}$ & $500(40)$ & 65 & composite:AB:PVdF (80:10:10) \\
\hline & 51 & $\begin{array}{l}\text { Dispersed S particles on spherical } \\
\text { PPy nanoparticles }\end{array}$ & $\begin{array}{l}\text { PPy via oxidative polymerization. The S-PPy by in } \\
\text { situ deposition from a chemical reaction at room }\end{array}$ & 0.5 & $\begin{array}{l}525(50) \\
525(50) \\
475(50)\end{array}$ & $\begin{array}{l}53 \\
64 \\
77\end{array}$ & $\begin{array}{c}\text { composite:Super P:PVdF } \\
\text { (60:20:20) }\end{array}$ \\
\hline & 42 & $\begin{array}{l}\text { Shaped S coated with PPy } \\
\text { nanolayer }\end{array}$ & $\begin{array}{c}\text { Sulfur particles by a chemical reaction at room } \\
\text { temperature. PPy via in situ oxidative } \\
\text { polymerization. }\end{array}$ & 0.2 & $>634(50)$ & 63.3 & $\begin{array}{c}\text { composite:Super P:PVdF } \\
(60: 20: 20)\end{array}$ \\
\hline & 53 & $\begin{array}{l}\text { S particles encapsulated by } \\
\text { polymers with a rough surface }\end{array}$ & $\begin{array}{l}\text { Sulfur particles by poly(allylamine } \\
\text { hydrochloride)/poly(styrenesulfonate) layers via } \\
\text { assembly technique. PANI-coated sulfur by } \\
\text { oxidative polymerization and PPy-coated sulfur via } \\
\text { assembly technique. }\end{array}$ & NR & NR & NR & NR \\
\hline \multirow[t]{6}{*}{$\begin{array}{l}\text { Polyaniline- } \\
\text { sulfur }\end{array}$} & 46 & three-dimensional urchine-like & $\begin{array}{l}\text { S-PANI via heterogeneous } S \text { nucleation reaction and } \\
\text { in situ oxidative polymerization. }\end{array}$ & $\begin{array}{c}0.1 \\
1\end{array}$ & $\begin{array}{l}964(50) \\
609(100)\end{array}$ & 55 & No binder or conducting agent \\
\hline & 54 & core-shell & $\begin{array}{l}\text { S-PANI via heterogeneous nucleation reaction and } \\
\text { in situ oxidative polymerization. }\end{array}$ & 1 & $867(100)$ & 65 & $\begin{array}{c}\text { composite:Super P:PTFE } \\
(70: 20: 10)\end{array}$ \\
\hline & 55 & nanotubes & PANI-NT via oxidative polymerization. & 0.1 & $837(100)$ & 62 & composite:Super P:PVdF \\
\hline & & & SPANI-NT/S via in situ vulcanization process. & $\begin{array}{c}0.5 \\
1\end{array}$ & $\begin{array}{l}614(100) \\
568(100)\end{array}$ & & $(80: 10: 10)$ \\
\hline & 56 & $\begin{array}{l}\text { sulfur power coated by PANI } \\
\text { layers }\end{array}$ & $\begin{array}{l}\text { PANI via polymerization process. PANI-Sulfur by } \\
\text { ball milling and heat-treatment. }\end{array}$ & 0.2 & $500(50)$ & 31 & $\begin{array}{c}\text { composite:VGCF:PVdF: PEO } \\
\text { (70:20:8:2) }\end{array}$ \\
\hline & 43 & $\begin{array}{l}\text { dual shell hollow PANI-S } \\
\text { core-PANI }\end{array}$ & hPANI/S/PANI via in situ successive deposition. & 0.1 & $572.2(214)$ & 73.5 & composite:AB:PVdF (80:10:10) \\
\hline \multirow{6}{*}{$\begin{array}{l}\text { Polyacrylonitrile- } \\
\text { sulfur }\end{array}$} & 45 & amorphous & S/DPAN by ball milling and a heat-treatment. & 0.2 & $495(50)$ & 53.5 & composite:KB:PVdF (80:10:10) \\
\hline & 62 & original network -like & $\begin{array}{l}\text { S/PAN via in situ polymerization followed and } \\
\text { heat-treatment in argon atmosphere. }\end{array}$ & $\begin{array}{c}0.5 \\
1\end{array}$ & $\begin{array}{l}\sim 1200(100) \\
\quad 981(100)\end{array}$ & 41 & composite:AB:PVdF (80:10:10) \\
\hline & 61 & amorphous & $\begin{array}{l}\text { S/DPAN by ball milling and a heat-treatment in } \\
\text { argon atmosphere varying time. }\end{array}$ & 0.2 & $1000(5)$ & 56 & composite:KB:PVdF (80:10:10) \\
\hline & 60 & $\begin{array}{l}\text { linear aromatic fused ring which } \\
\text { contain bonded } \mathrm{S} \text { side chains }\end{array}$ & $\begin{array}{l}\text { Sulfur-PAN based material by ball milling and a } \\
\text { heat-treatment varying temperature. }\end{array}$ & $100 \mathrm{~mA} \mathrm{~g}^{-1}$ & $\begin{array}{l}1323(50) \\
1904(50) \\
1340(50)\end{array}$ & 42 & composite:AB:PAN (80:10:10) \\
\hline & 63 & amorphous & $\begin{array}{l}\text { Sulfur-containing PAN by a chemical } \\
\text { method-suspension polymerization. }\end{array}$ & 0.1 & $400(30)$ & 33.4 & composite:AB:PTFE (70:20:10) \\
\hline & 64 & $\begin{array}{l}\text { agglomerates with homogeneous } \\
\text { surface }\end{array}$ & $\begin{array}{l}\text { SPAN by heating a mixture of polyacrylonitrile } \\
\text { power and sublimed sulfur. A new binder was added. }\end{array}$ & 0.9 & $938(500)$ & 32 & $\begin{array}{c}\text { composite:carbon black:NaCMC } \\
\text { (70:15:15) }\end{array}$ \\
\hline \multirow[t]{2}{*}{$\begin{array}{l}\text { Commercial } \\
\text { rubber-sulfur }\end{array}$} & 44 & cross-linked confinement & Vulcanization process in nitrogen atmosphere. & 0.1 & $671(50)$ & $\sim 91$ & $\begin{array}{c}\text { composite:Super P:PVdF } \\
\text { 70:20:10) }\end{array}$ \\
\hline & 65 & S-rich polymer chain network & Vulcanization process in nitrogen atmosphere. & $1 \mathrm{~mA} \mathrm{~cm}^{-2}$ & $\begin{array}{l}586(100) \\
520(100)\end{array}$ & $\begin{array}{l}89 \\
84\end{array}$ & composite:AB:PVdF (75:20:5) \\
\hline $\begin{array}{l}\text { Polythiophene- } \\
\text { sulfur }\end{array}$ & 57 & core-shell & $\begin{array}{l}\text { S-PTh via in situ chemical oxidative polymerization } \\
\text { method. }\end{array}$ & $100 \mathrm{~mA} \mathrm{~g}^{-1}$ & $830.2(80)$ & 71.9 & $\begin{array}{c}\text { composite:carbon black:PVdF } \\
\text { (70:20:10) }\end{array}$ \\
\hline $\begin{array}{l}\text { vegetable } \\
\text { oils-sulfur }\end{array}$ & 66 & amorphous crosslinked network & Bulk copolymerization of $\mathrm{S}$ and vegetable oils. & 0.1 & $550(100)$ & 80 & $\begin{array}{c}\text { composite:Super C65:PVdF } \\
(70: 20: 10)\end{array}$ \\
\hline
\end{tabular}


$100 \mathrm{~mA} \mathrm{~g}{ }^{-1} \cdot{ }^{50}$ Both synthesis processes were carried out without applying any heat-treatment.

Yuan's group also reported a S/PPy composite with nanosized core-shell structure, ${ }^{47}$ synthesized via in situ polymerization, at room temperature for $2.5 \mathrm{~h}$, of pyrrole on the surface of sulfur particles. The difference with the previous report, is that Yuan et al. carried out their synthesis in the presence of surfactant. An initial discharge capacity of $1039 \mathrm{~mA} \mathrm{~h} \mathrm{~g}^{-1}$ at $0.1 \mathrm{C}$ was achieved. A capacity of $613 \mathrm{~mA} \mathrm{~h} \mathrm{~g}^{-1}$ after 50 cycles at $0.1 \mathrm{C}$ was maintained.

Xu et al. synthesized sulfur@polypyrrole (S@PPy) core-shell spheres as cathode material. ${ }^{49}$ The S@PPy composite was prepared via in situ polymerization, a process that did not require the use of either a template or heat treatments. The aggregation and size of sulfur particles were controlled, furthermore a uniform coating layer of PPy and core-shell structure were obtained. The composite electrode showed an initial discharge capacity of $1142 \mathrm{~mA} \mathrm{~h} \mathrm{~g}^{-1}$ and a capacity retention of $805 \mathrm{~mA} \mathrm{~h} \mathrm{~g}^{-1}$ after 50 cycles at $0.1 \mathrm{C}$.

Manthiram et al. studied the preparation of materials by varying the polypyrrole and sulfur ratios by an in situ deposition method, ${ }^{51}$ at room temperature overnight, to synthesize sulfur particles in the presence of polypyrrole which had previously been prepared by the polymerization of pyrrole monomer at $0-5^{\circ} \mathrm{C}$ overnight and using ammonium peroxydisulfate as an oxidant. Three S-PPy composites with different sulfur contents were obtained. These three samples were designated as S-PPy-53, S-PPy-64 and S-PPy-77 with 53 wt\%, $64 \mathrm{wt} \%$ and $77 \mathrm{wt} \%$ sulfur content respectively. Differences in the initial discharge capacity were observed between the different electrodes, but, surprisingly, the capacity retention after 50 cycles was identical for S-PPy-53 and S-PPy-64, and only 10\% lower for S-PPy77. According to authors the formation of small sulfur particles was favored by increasing the amount of polymer. Therefore, the polymer would be acting not only as a conductive matrix but also as a dispersing material, further increasing the porosity of the electrode. In this work, a conductive agent has also been incorporated during the preparation of the cell to evaluate the electrochemical performance. The cathodes were prepared by mixing $60 \mathrm{wt} \%$ active material, 20 wt $\%$ Super P carbon as conductive agent and $20 \mathrm{wt} \% \mathrm{PVdF}$ as binder.

Polyaniline is another polymer that has been frequently reported for the synthesis of sulfur cathode composites. Simple synthesis pathways, including some where it was even not necessary to use organic solvents neither heating stages were reported.

Duan et al. proposed the synthesis of two different polymer-coated sulfur composites as cathode materials obtained via a layer-by-layer self-assembly technique. ${ }^{53}$ Firstly, the sulfur particles were covered with poly(allylamine hydrochloride) (PAH) and poly(styrenesulfonate sodium salt) (PSS), through layer-by-layer electrostatic self-assembly. Positively charged PAH and negatively charged PSS were alternatively adsorbed onto the surface of the sulfur particles, thus forming PAH/PSS multilayers. The process also involves the addition of glutaraldehyde (GA) and a heat-treatment. Secondly, in order to improve the conductivity, these as-prepared sulfur particles were covered by either PANI or PPy casings by an in-situ oxidative polymerization at $0-3^{\circ} \mathrm{C}$ for $24 \mathrm{~h}$, and electrostatic interaction respectively. Unfortunately, no electrochemical essays were reported, i.e. the potential utilization of this material in lithium-sulfur cells is at this stage merely a speculation.

Wang et al. proposed the synthesis of S-PANI composite with urchine-like structures via heterogeneous sulfur nucleation reaction and in situ oxidative polymerization, ${ }^{46}$ achieving at $0.1 \mathrm{C}$ an initial discharge capacity of $1095 \mathrm{~mA} \mathrm{~h} \mathrm{~g}^{-1}$. The capacity retention was of $964 \mathrm{~mA} \mathrm{~h} \mathrm{~g}^{-1}$ after 50 cycles. At $1 \mathrm{C}$ an initial discharge capacity $689 \mathrm{~mA} \mathrm{~h} \mathrm{~g}^{-1}$ was achieved. A capacity retention of $609 \mathrm{~mA} \mathrm{~h} \mathrm{~g}^{-1}$ after 100 cycles was observed. The sulfur content was lower than that reported for other similar materials; however, it is important to note that in this case no addition of any conductive agent for the assembly of the electrode was performed.

Wang's group synthesized a core-shell S-PANI composite with 65 wt $\%$ sulfur content, by heterogeneous sulfur nucleation reaction and in situ polymerization at room temperature for $24 \mathrm{~h} .{ }^{54}$ The synthesis was performed in aqueous medium, without the need of an inert atmosphere, and without heating steps either. At a high discharge rate of $1 \mathrm{C}$, an initial discharge capacity of $977 \mathrm{~mA} \mathrm{~h} \mathrm{~g}^{-1}$ was achieved. Capacity retention of $867 \mathrm{~mA} \mathrm{~h} \mathrm{~g}^{-1}$ after 100 cycles was obtained, producing the best results for a S-PANI compound. However, here the S-PANI composites were mixed with $20 \mathrm{wt} \%$ conductive carbon black and $10 \mathrm{wt} \%$ polytetrafluoroethylene (PTFE) as binder.

The synthesis via in situ vulcanization process at $280^{\circ} \mathrm{C}$ for $12 \mathrm{~h}$ of encapsulated sulfur in PANI nanotubes was reported by Liu et al ${ }^{55} \mathrm{At}$ a discharge rate of $1 \mathrm{C}$, an initial discharge capacity of $511 \mathrm{~mA} \mathrm{~h} \mathrm{~g}^{-1}$ was achieved. Capacity retention of $568 \mathrm{~mA} \mathrm{~h} \mathrm{~g}^{-1}$ was maintained after 100 cycles. The results are similar to those obtained by Wang's group for sulfur-PANI with urchine-like structures. However, a smaller amount of conductive agent was used in the mixture prepared to build up the test cell.

A PANI-coated sulfur composite was reported by Ishihara et al. ${ }^{56}$ It was synthesized via in situ polymerization where sulfur powder was used, producing a highly homogeneous $\mathrm{S}$ distribution. Results were presented for different $\mathrm{S}$ content, with $19 \mathrm{wt} \%, 31 \mathrm{wt} \%$ and $54 \mathrm{wt} \%$. The best performance was shown by the composite with 31 $\mathrm{wt} \%$ that showed an initial discharge capacity of $903 \mathrm{~mA} \mathrm{~h} \mathrm{~g}^{-1}$ and approximately $500 \mathrm{~mA} \mathrm{~h} \mathrm{~g}^{-1}$ after of 50 cycles at $0.2 \mathrm{C}$ were obtained for sulfur-PANI.

Fan et al. proposed a dual-shell hollow polyaniline/sulfurcore/polyaniline (hPANI/S/PANI) as a new composite for sulfur cathodes. ${ }^{43}$ The hPANI/S/PANI was synthesized by successively depositing PANI, $\mathrm{S}$ and again PANI using a silicone sphere as sacrificial template. Firstly, the SS/PANI composite was prepared by mixing template silicon spheres (SS), a surfactant (CTAB), aniline, $\mathrm{HCl}$ and $\mathrm{Na}_{2} \mathrm{~S}_{2} \mathrm{O}_{8}$ under stirring at $0^{\circ} \mathrm{C}$. Secondly, the SS/PANI/S composite was prepared from by mixing SS/PANI, $\mathrm{Na}_{2} \mathrm{~S}_{2} \mathrm{O}_{3}$ and $\mathrm{HCl}$, and stirring at room temperature. Thirdly, following similar conditions to those of the first step, PANI was again deposited on the SS/PANI/S surface. Finally, the SS/PANI/S/PANI was etched in HF and the hPANI/S/PANI composite was obtained. The core-shell nanostructure allowed a homogeneous distribution of sulfur particles. Therefore, a stabilized structure and enhanced conductivity were achieved. At $0.1 \mathrm{C}$ an initial discharge capacity of $497.9 \mathrm{~mA} \mathrm{~h} \mathrm{~g}^{-1}$ was observed and a discharge capacity of $572.2 \mathrm{~mA} \mathrm{~h} \mathrm{~g}^{-1}$ after 214 cycles at same rate was remained.

Interestingly, some authors observed that the specific capacity is lower for the very first cycles, with a subsequent increase, and later on following the gradual loss of capacity normally encountered for lithium-sulfur batteries. ${ }^{43,55}$ According to the authors, this behavior indicates the presence of an activation stage for the composite material, involving the diffusion and full penetration, i.e. wetting, of the electrolyte inside the electrode. Contacting the electrolyte with the sulfur-polymer species is a necessary step for the electrochemical activation.

The Chen's group proposed the synthesis of a material using polythiophene as the polymeric matrix. ${ }^{57}$ Polythiophene functions as a conductive additive and as a porous adsorptive agent. The reported sulfur content exceeds $80 \mathrm{wt} \%$. However electrochemical studies were evaluated at a low current density. An initial discharge capacity of $1193 \mathrm{~mA} \mathrm{~h} \mathrm{~g}^{-1}$ was achieved at a current density of $100 \mathrm{~mA} \mathrm{~g}^{-1}$. A capacity of $830 \mathrm{~mA} \mathrm{~h} \mathrm{~g}^{-1}$ after 80 cycles remained. The material was synthesized by in situ polymerization method at $0{ }^{\circ} \mathrm{C}$ for $10 \mathrm{~h}$ and for the electrochemical tests the addition of $20 \mathrm{wt} \%$ carbon black was necessary.

The use of PAN as a non-conductive polymeric matrix was reported by Wang et al. as early as $2002 .{ }^{58}$ The S-PAN composite is one of the most promising polymeric host material for use in lithiumsulfur batteries. Although PAN is an insulating polymer, it covalently attaches to $S_{x}$ chains, forming a new chemical compound. Therefore, important changes on the final PAN-modified polymeric structure are observed, and these give rise to a modified electrochemical mechanism that explains the unique results obtained for S-PAN systems. ${ }^{59} \mathrm{Sev}$ eral different polymeric composites showed capacity retention values above $900 \mathrm{~mA} \mathrm{~h} \mathrm{~g}^{-1}$ after 100 cycles (see Table I). However, we are 
obliged to make the remark that the sulfur content of all these compounds is relatively low, the highest report being $56 \mathrm{wt} \%$, i.e. while the discharge capacity expressed by S content is very good, if we look at the cell, or the cathode as a whole (weight of polymer, conductive agent and binder included) the specific energy of the cell decreases, since $S$ is no longer a major component in the cathode. ${ }^{45,60-62}$

Zhu et al. reported a sulfur-containing PAN composite that was synthesized following a simple and economic pathway. ${ }^{63}$ The synthesis method consisted in the addition of dimethyl formamide, acrylonitrile and sublimed sulfur to an aqueous solution of polyvinyl alcohol (dispersing agent) at $65^{\circ} \mathrm{C}$. Azodiisobutyronitrile was added to promote the reaction. The as-prepared precursor was heated to $300^{\circ} \mathrm{C}$ under nitrogen atmosphere for $8 \mathrm{~h}$ and the sulfur-containing PAN material was obtained. This composite, with $33.4 \mathrm{wt} \%$ sulfur content, showed an initial capacity of $546.6 \mathrm{~mA} \mathrm{~h} \mathrm{~g}^{-1}$ at $0.1 \mathrm{C}$, with a remaining capacity of $400 \mathrm{~mA} \mathrm{~h} \mathrm{~g}^{-1}$ after 30 cycles. A big initial capacity loss was observed, that, according to the authors, it can be attributed to the irreversible conversion of active material. The sulfur particle size and the microstructure contributed to the enhanced cycle performance.

He et al. studied the effect of temperature during synthesis on the electrochemical properties of S-PAN compounds. ${ }^{60}$ An S-PAN material with a sulfur content of $42 \mathrm{wt} \%$ was prepared by mixing sulfur and PAN by ballmilling. Then, the S-PAN-based material was prepared by heating for $5 \mathrm{~h}$ varying the temperature from $120^{\circ} \mathrm{C}$ to $400^{\circ} \mathrm{C}$ for $5 \mathrm{~h}$. The optimal temperature was found to be $350^{\circ} \mathrm{C}$. For this compound, an initial discharge capacity of $2356 \mathrm{~mA} \mathrm{~h} \mathrm{~g}^{-1}$ was obtained at 100 $\mathrm{mA} \mathrm{g}^{-1}$. After 50 cycles, a capacity retention of $1904 \mathrm{~mA} \mathrm{~h} \mathrm{~g}^{-1}$ was achieved. This capacity value is much higher than the theoretical maximum capacity of S. According to the authors, this anomalous value indicates that the PAN-derived backbone is significantly contributing to the capacity, i.e. PAN is no longer acting as a supporting matrix for $\mathrm{S}$ only, but is actively taking place in the energy storage process.

Chen et al. tried to understand the effect of the synthesis parameters in the structural changes on the S-PAN compounds. Thus, in a first article a discussion about the binding mechanism of sulfur to polyacrylonitrile, the upper limit of the sulfur content and the heattreatment time was presented. ${ }^{61}$ An S-PAN composite was prepared by ballmilling a mixture of sulfur and PAN. Then, a heat-treatment at $300^{\circ} \mathrm{C}$ under argon atmosphere, varying the heating time from $0.5 \mathrm{~h}$ to $4 \mathrm{~h}$ was performed. The loss of mass of sulfur due to its volatilization and formation of $\mathrm{H}_{2} \mathrm{~S}$ (PAN dehydrogenation reaction) is determined experimentally as a function of the heating time. A value of about $56 \mathrm{wt} \%$ is found as the upper limit of sulfur content and it is further verified from a theoretical calculation. It is found that a heating time of $2.5 \mathrm{~h}$ is sufficient to complete the dehydrogenation reaction of the polyacrylonitrile and to remove sulfur in excess by volatilization thereof. With regards to electrochemical assays, the authors observed that the specific discharge capacity increases with the heat-treatment time until $2.5 \mathrm{~h}$. Subsequently, for longer heating periods, the specific discharge capacity decreased.

The capacity and cyclability of lithium-sulfur batteries have improved using polyacrylonitrile for the synthesis of a composite cathode material; however, the loss of capacity remains unresolved. In a second work, Chen's group investigated the changes in cathode properties that occur during charge-discharge cycling of the battery. ${ }^{45}$ The S-PAN cathode material was prepared by milling a mixture of sulfur and PAN followed by a heat-treatment at $300^{\circ} \mathrm{C}$ for $4 \mathrm{~h}$. An S- dehydrogenated PAN compound having a sulfur content of $54 \mathrm{wt} \%$ is obtained. The accumulation of sulfur on the surface of the compound was observed by characterization techniques such as SEM, XRD, and FTIR; decreasing with the increase in the number of cycles. From an EIS analysis it was observed that the loss of capacity can be attributed to the formation and irreversible accumulation of the insoluble $\mathrm{Li}_{2} \mathrm{~S}$ and $\mathrm{Li}_{2} \mathrm{~S}_{2}$ species on the cathode surface.

In the last work, Chen et al. reported an S-PAN composite synthesized by a different path. ${ }^{62}$ The development of a new technique arises from the need to obtain a compound with a homogeneous distribution of sulfur in the polymer structure. The synthesis method consists of an in situ polymerization of acrylonitrile with sulfur nanoparticles at $70^{\circ} \mathrm{C}$ for $10 \mathrm{~h}$ involving a heating step at $350^{\circ} \mathrm{C}$ for $6 \mathrm{~h}$ in argon atmosphere. The as-prepared composite had a highly developed network structure. A uniform distribution of sulfur and no changes in the morphology of the material were observed after the cycling process. The structure of the compound allows accommodating volume changes of the cathode without an agglomeration and degradation of the material take place. The morphological stability of the composite and its electrochemical performance is improved with regard to S-PAN composites obtained by ballmilling. ${ }^{45,61}$

Wang et al. compared the use of sodium carboxymethyl cellulose (NaCMC) with poly(vinylpyrrolidone) (PVdF) as cathode binder in sulfurized polyacrylonitrile (SPAN) cathodes. ${ }^{64}$ The composite material, with $32 \mathrm{wt} \%$ sulfur content, was synthesized by heating a mixture of PAN powder and sublimed sulfur at $350^{\circ} \mathrm{C}$ for $12 \mathrm{~h}$. Cathode were prepared by mixing the active material, carbon black as a conductive agent and alternatively $\mathrm{NaCMC}$ or PVdF as binder agents in weight ratio of $75: 15: 15$, respectively. $\mathrm{NaCMC}$ was reported to enhance the cathode performance. PVdF seems to only allow for good performance at low discharge currents. According to the authors, the unique chemical composition of $\mathrm{NaCMC}$ allows for the high capacity to be maintained even at high discharge rates. A high reversible capacity of $938 \mathrm{~mA} \mathrm{~h} \mathrm{~g}^{-1}$ after the astounding figure of 500 cycles at $0.9 \mathrm{C}$ was obtained.

Two novel sulfur rich polymeric composite, using rubber as a raw material have been reported by Meng et al. ${ }^{44,65}$ These rubbers are commercially available and are certainly inexpensive. In both reports, the synthesis method involves a vulcanization process. This process consists of preparing a mixture with the rubber and a certain amount of sulfur and maintaining it in an oil bath at a relatively moderate temperature $\left(140 / 200^{\circ} \mathrm{C}\right)$ and under an inert atmosphere. Upon cooling to room temperature, the sulfur-rich polymer composite is obtained. Before mixing with sulfur, two different treatments for the rubber have been carried out. In a first approach, a certain amount of polysulfide rubber was frozen with liquid nitrogen for subsequent crushing. ${ }^{65}$ In the second approach, the butadiene rubber was dissolved in decahydronaphthalene. ${ }^{44}$ With regards to electrochemical performance, for the material prepared from butadiene rubber, the initial discharge capacity was of $811 \mathrm{~mA} \mathrm{~h} \mathrm{~g}^{-1}$ at $0.1 \mathrm{C}$. For the composite obtained from polysulfide rubber, an initial discharge capacity of $923 \mathrm{~mA} \mathrm{~h} \mathrm{~g}^{-1}$ was achieved.

Theato et al. proposed the synthesis of sulfur-base polymer composites from vegetable oils. ${ }^{66}$ Three different vegetable oils, linseed oil (LSO), sunflower oil (SFO) and olive oil (OO) were used. The composites were prepared by a simple and practical copolymerization process. Elemental sulfur and vegetable oil were mixed under stirring in a mass ratio ranging from 50 to $80 \mathrm{wt} \%$ sulfur and heated at $170^{\circ} \mathrm{C}$ for $60 \mathrm{~min}$ to achieve a homogenization of the mixture, which is crucial to obtain the amorphous rubber-like products. With regards to cyclic performance of the compounds with $80 \mathrm{wt} \%$ sulfur content, initial specific capacities above $800 \mathrm{~mA} \mathrm{~h} \mathrm{~g}^{-1}$ were achieved in all cases. Capacity retention of $500 \mathrm{~mA} \mathrm{~h} \mathrm{~g}^{-1}$ after 100 cycles at $0.1 \mathrm{C}$ were reported.

As shown above, a larger number of publications have been reported in the last years for new polymeric cathode materials. Of all revised polymers, PANI, PPy and PTh are characterized as conducting polymers. Interestingly, the incorporation of these compounds not only improves the conductivity of the electrode. In addition, they function as adsorbent agents for active materials due to presence of polar functional groups which interact with both sulfur and polysulfides through electrostatic interaction or bonding.

Those polymers that are not characterized as conductive properties, namely PSS and PAH, can function simply as physical barriers preventing the diffusion and dissolution of polysulfides. More interesting, is the case of non-conductive polymers such as PAN, commercial rubbers and vegetable oils. In the case of those polymers, they not only allow for sulfur encapsulation. In addition, a small fraction of sulfur becomes part of the polymeric structure through S-C bonding, resulting in the formation of a new compound enriched in sulfur. Finally, for all polymers, their mechanical properties stabilized the 
whole electrode structure, during the volume changes that take place during the charge-discharge process.

With respect to the synthesis methods, it is important to highlight those cases where a direct methodology was proposed, consisting an in situ polymerization (see Table I for details). The morphology of the material and its stability during the cycling process, together with a homogeneous distribution of sulfur, are important factors to improve the electrochemical performance of the cell as a whole. The strong physical and/or chemical confinement of the active material within the electrode was attributed not only to the properties of the original polymers, but also to the obtained nanostructures and the overall electrode architecture, that played an important role. For example, the core-shell structures contribute to improve the use of the active material and decrease the solubility of the polysulfides. Meanwhile, the void spaces of the said structures increased the contact area between the electrode and the electrolyte and allowed the volume changes to be accommodated.

\section{Sulfur-Metal Oxide Composite Cathode Materials}

The possibility to capture soluble polysulfides in adsorbent materials such as carbonaceous materials and oxides is a most promising alternative. Although the electric conductivity is certainly higher in carbonaceous materials, metal oxides or semi-conductors, such as $\mathrm{TiO}_{2}$ and $\mathrm{MnO}_{2}$, display much stronger binding energy to sulfur compounds than carbons. Thus, the focus of attention was directed toward the use of oxides as additives or adsorbents due to its strong chemical adsorption with the polysulfides. ${ }^{67}$ In addition, it is easy to synthesize these oxides with porous structures that allow the trapping of polysulfides, while void space allows to accommodate the volume changes that occur during the cycling process. Table II gathers the most important data of articles reporting the use of metal oxides in sulfur cathodes published since 2010 .

Titanium oxide $\left(\mathrm{TiO}_{2}\right)$ has been repeatedly reported as host material for sulfur cathodes. Different techniques were used for the synthesis of $\mathrm{TiO}_{2}$ before its combination with sulfur, including sol-gel method, ${ }^{68}$ electrospinning technique ${ }^{69}$ and hydrothermal process. ${ }^{70}$ $\mathrm{Li}$ et al. starts with the synthesis of sols which are then transformed in gels. Titanium (IV) isopropoxide is dissolved in absolute ethanol and distilled water and maintained under stirring. After aging, the sols were transformed into gels which were dried and sintered at $120^{\circ} \mathrm{C}$ and $500^{\circ} \mathrm{C}$ respectively, obtaining $\mathrm{TiO}_{2}$ nanoparticles. In the electrospinning technique, reported by Wang's group; poly-vinylpyrrolidone, ethanol, acetic acid and tetrabutyltitanate were mixed and then stirred at room temperature. The as-obtained $\mathrm{TiO}_{2}$ nanofibers were electrospun using a high voltage power supply, then collected and finally calcined at $500^{\circ} \mathrm{C}$ for $6 \mathrm{~h}$. Wei et al. carried out a hydrothermal process, in which an alkaline solution of $\mathrm{TiO}_{2}$ was heat in a silicon oil bath at $150^{\circ} \mathrm{C}$ for $24 \mathrm{~h}$ with stirring. The obtained sodium titanate was subjected to a hydrogen ion exchange process in nitric acid. The hydrogen titanate nanotubes were heated at $450^{\circ} \mathrm{C}$ for $2 \mathrm{~h}$, to produce $\mathrm{TiO}_{2}$ nanotubes. Overall, using different synthesis methodologies it is possible to obtain varied morphologies for $\mathrm{TiO}_{2}$, such as nanoparticles, nanofibers and nanotubes.

In all three reports, the $\mathrm{TiO}_{2}-\mathrm{S}$ composites were prepared by a simple melt-diffusion process where elemental sulfur was mixed with either $\mathrm{TiO}_{2}$ nanoparticles, nanofibers or nanotubes by ballmilling, then dried and heated at approximately $150^{\circ} \mathrm{C}$ using a tubular furnace under argon atmosphere ${ }^{68}$ or in an autoclave. ${ }^{69}$ The sulfur content in these materials ranges from $55 \mathrm{wt} \%$ to $65 \mathrm{wt} \%$.

Both anatase $\mathrm{e}^{68,70}$ and anatase-rutile microcrystal ${ }^{69}$ structures for titanium oxides have been reported. X-ray diffraction has been used to search potential structural changes of the start reagents, metal oxides and sulfur particles; due to their possible interactions. According to the authors, a decrease in the sulfur peak intensity confirms a very good dispersion of the element into the porous material.

In all three cases, the composite cathodes were prepared by mixing the active material with acetylene black as a conductive agent in different proportions and the electrochemical studies were carried out at a discharge rate of $0.2 \mathrm{C}$. Zhang's group achieved the best result for initial discharge capacity, obtaining a result of $1460 \mathrm{~mA} \mathrm{~h} \mathrm{~g}^{-1}$. While a capacity retention of $680 \mathrm{~mA} \mathrm{~h} \mathrm{~g}^{-1}$ after 100 cycles was reported. ${ }^{68}$ While Wei's composite cathode achieved an initial discharge capacity of $913 \mathrm{~mA} \mathrm{~h} \mathrm{~g}^{-1}$, an impressive capacity retention of $851 \mathrm{~mA} \mathrm{~h} \mathrm{~g}^{-1}$ after 100 cycles was reported, which it is about $90 \%$ of the initial value. It should be noted, however, that a greater amount of acetylene black as conductive agent was used in the latter case, $20 \mathrm{wt} \%$ vs $10 \mathrm{wt} \%{ }^{70}$ Wang et al. ${ }^{69}$ obtained a similar result to Wei's group for initial discharge capacity. However, much lower capacity retention was achieved after 50 cycles only.

In addition, Wei et al. studied variations in performance with $\mathrm{TiO}_{2}$ $\mathrm{S}$ ratio. ${ }^{70} \mathrm{TiO}_{2}$ nanotubes and elemental sulfur were mixed with mass ratios of $1: 1$ and $1: 2$, respectively. For $\mathrm{TiO}_{2}-\mathrm{S} 1: 2$, the capacity retention was $851 \mathrm{~mA} \mathrm{~h} \mathrm{~g}^{-1}$ at $0.2 \mathrm{C}$ after 100 cycles achieving the best cycling stability vs. other $\mathrm{TiO}_{2}$ composites. According to the authors, this result can be attributed to the good sulfur dispersion on $\mathrm{TiO}_{2}$ nanotubes and the strong electrostatic interaction between them, retaining the soluble polysulfides and decreasing the shuttle effect. Furthermore, by EIS spectra, a charge-transfer resistance lower than that of elemental sulfur was observed for the $\mathrm{TiO}_{2}-\mathrm{S}$ composite. Together, the better conductivity of $\mathrm{TiO}_{2} \mathrm{vs} \mathrm{S}$, and the nanotube structure which allows the absorption of polysulfides, help to achieve composite cathodes with lower charge-transfer resistances.

Two reports proposing the use of $\mathrm{MnO}_{2}$ as host material for sulfur cathodes have been published. $\mathrm{MnO}_{2}-\mathrm{S}$ compounds have yielded the best results of all reported metal-oxide compounds for sulfur cathodes. Two different routes were proposed for the synthesis of the $\mathrm{MnO}_{2}$ $\mathrm{S}$ composites. Wang et al. ${ }^{71}$ firstly prepared mesoporous $\mathrm{MnO}_{2}$ by hard template method where manganese nitrate dissolved in ethanol was used to impregnate a silica template previously synthesized; this mixture was stirred, calcined at $350^{\circ} \mathrm{C}$ for $3 \mathrm{~h}$ and treated with $\mathrm{NaOH}$ to dissolve the template. Finally, $\mathrm{MnO}_{2}-\mathrm{S}$ was prepared by a typical melt-diffusion process. Conversely, Nazar et al ${ }^{67}$ prepared a core-shell $\mathrm{MnO}_{2}-\mathrm{S}$ composite by a reaction between potassium permanganate and sulfur particles under ambient conditions and in aqueous solution. Furthermore, the performance when using commercial sulfur particles was compared to sulfur nanoparticles. Only the best results have been gathered in Table II.

It is interesting to point out, that for $\mathrm{MnO}_{2}-\mathrm{S}$, it has been possible to synthesize compounds with a wide range of sulfur content, albeit not always with the same $\mathrm{MnO}_{2}$ morphology and binder/conductive agent content. For example, Wang's group ${ }^{71}$ proposed materials with low sulfur content; variating its weight ratio between 10-40 wt\% while Nazar's group ${ }^{67}$ has reported materials with high sulfur content, with values close to $80 \mathrm{wt} \%$. Conversely, for other metal oxides, only compounds within a narrow range of $\mathrm{S}$ content have been reported (e.g. $\mathrm{Co}_{3} \mathrm{O}_{4}$ ). For electrochemical studies, the composite cathodes were prepared using two different conductive agents. $\mathrm{MnO}_{2}-\mathrm{S}$ composites synthetized by Wang et al. were mixed with acetylene black and PVdF binder in a weight ratio of 70:20:10. While $80 \mathrm{wt} \%$ of Nazar's binary composite was mixed with $10 \mathrm{wt} \%$ Super P and $10 \mathrm{wt} \% \mathrm{PVdF}$. It is also important to take into account that the assays performed by Nazar et al. have been evaluated at a much higher rate. For a sulfur content of $80 \mathrm{wt} \%$, Nazar et al. reported an initial discharge capacity of a capacity retention of $1079 \mathrm{~mA} \mathrm{~h} \mathrm{~g}^{-1}$, and capacity retention values of $950 \mathrm{~mA} \mathrm{~h} \mathrm{~g}^{-1}$ after 300 cycles at $0.5 \mathrm{C}$. Interestingly, when the same cells were evaluated at $2 \mathrm{C}$, the initial discharge capacity was hardly compromised, and a third of that capacity still remained after 1700 cycles.

Later, Wang et al. ${ }^{72}$ proposed the use of $\mathrm{Co}_{3} \mathrm{O}_{4}$ as a new metal oxide host material. Firstly, to achieve the synthesis of $\mathrm{Co}_{3} \mathrm{O}_{4}$ nanotubes, a precursor was obtained by a precipitation reaction taking place between cobalt chloride and an oxalic acid solution, followed by treatment with a sodium hydroxide solution. The final precipitate was filtered, washed, dried at $50^{\circ} \mathrm{C}$ for $24 \mathrm{~h}$, and calcined at $350^{\circ} \mathrm{C}$ for $3 \mathrm{~h}$ to obtain the oxide. The $\mathrm{Co}_{3} \mathrm{O}_{4}-\mathrm{S}$ composite was prepared via melt-diffusion strategy at $155^{\circ} \mathrm{C}$ varying the sulfur content from 10 $\mathrm{wt} \%$ to $40 \mathrm{wt} \%$. It was found that the capacity retention decreases 
Table II. Summary of reported results for metal oxide-sulfur binary compounds reported in the literature since 2010. AB: acetylene black; PVdF: polyvinylidene fluoride; CMC: carboxymethyl cellulose; NR: not reported.

\begin{tabular}{|c|c|c|c|c|c|c|c|}
\hline Composite & {$[\operatorname{Ref}]$} & Morphology & Synthesis method & $\begin{array}{l}\text { Current } \\
\text { rate/density } \\
{[C]}\end{array}$ & $\begin{array}{l}\text { Capacity } \\
\text { retention } \\
{\left[\mathrm{mA} \mathrm{h}^{-1}\right]} \\
\left(\mathrm{n}^{\circ} \text { cycles }\right)\end{array}$ & $\begin{array}{l}\text { Sulfur } \\
\text { content } \\
{[w t \%]}\end{array}$ & Cathode composition [wt $\%$ ] \\
\hline \multirow[t]{3}{*}{$\mathrm{TiO}_{2}$-sulfur } & 68 & $\begin{array}{c}\text { aggregation of micron-sized } \\
\text { sponge } \mathrm{TiO}_{2} \text { (anatase) } \\
\text { nanoparticles with irregular } \\
\text { pores. }\end{array}$ & $\begin{array}{l}\mathrm{TiO}_{2} \text { nanoparticles via sol-gel method, } \\
\text { sintered at } 500^{\circ} \mathrm{C} \text {. } \mathrm{TiO}_{2} \text {-sulfur by } \\
\text { melt-diffusion process. }\end{array}$ & 0.2 & $680(100)$ & 60.2 & composite:AB:PVdF (80:10:10) \\
\hline & 69 & $\begin{array}{l}\mathrm{TiO}_{2} \text { (anatase-rutile) nanofibers } \\
\text { are composed of nanoparticles } \\
\text { that possess nanoarchitecture } \\
\text { with internal void space. }\end{array}$ & $\begin{array}{l}\mathrm{TiO}_{2} \text { via electrospinning technique and } \\
\text { subsequent calcination at } 500^{\circ} \mathrm{C} \text {. } \mathrm{S}-\mathrm{TiO}_{2} \text { by } \\
\text { melt-diffusion process. }\end{array}$ & 0.2 & $530(50)$ & 57.5 & composite:AB:PVdF (70:20:10) \\
\hline & 70 & $\begin{array}{c}\mathrm{TiO}_{2} \text { (anatase) nanotubes, with } \\
\text { morphology continuous and } \\
\text { disorganized after encapsulating }\end{array}$ & $\begin{array}{l}\mathrm{TiO}_{2} \text { nanotubes by a hydrothermal process } \\
\text { and a subsequent thermal treatment at } \\
450^{\circ} \mathrm{C} . \mathrm{TiO}_{2 /} \mathrm{S} \text { by a melt-diffusion strategy. }\end{array}$ & 0.2 & $618(100)$ & 50 & composite:AB:PVdF (70:20:10) \\
\hline $\mathrm{MnO}_{2}$-sulfur & 71 & $\begin{array}{c}\text { of S. } \\
\text { highly ordered mesoporous } \\
\text { structure and highly crystalline } \\
\text { walls }\end{array}$ & $\begin{array}{l}\mathrm{MnO}_{2} \text { walls by hard template method and } \\
\text { calcination at } 350^{\circ} \mathrm{C} \text {. Mesoporous } \\
\beta-\mathrm{MnO}_{2} / \text { sulfur by melt-diffusion process. }\end{array}$ & $0.05 \mathrm{~mA} \mathrm{~cm}^{-2}$ & $\begin{aligned} & 851(100) \\
\sim & 1425(100) \\
\sim & 1350(100) \\
\sim & 1025(100) \\
\sim & 780(100)\end{aligned}$ & $\begin{array}{c}65 \\
9.3 \\
19.1 \\
30.0 \\
39.9\end{array}$ & composite:AB:PVdF (70:20:10) \\
\hline & 67 & core-shell and yolk-shell & $\begin{array}{l}\mathrm{S} / \mathrm{MnO}_{2} \text { via chemical reaction between } \\
\mathrm{KMnO}_{4} \text { and sulfur under room conditions in }\end{array}$ & 0.5 & $\begin{array}{l}680(300) \\
950(300)\end{array}$ & $\begin{array}{l}85 \\
80\end{array}$ & $\begin{array}{c}\text { composite:Super P:PVdF } \\
(80: 10: 10)\end{array}$ \\
\hline \multirow[t]{4}{*}{$\mathrm{Co}_{3} \mathrm{O}_{4}$-sulfur } & 72 & microporous hollow nanotubes & $\begin{array}{l}\text { aqueous solutions and washed with toluene. } \\
\mathrm{Co}_{3} \mathrm{O}_{4} \text { by a precipitation reaction and } \\
\text { calcination at } 350^{\circ} \mathrm{C} \text {. Sulfur } / \mathrm{Co}_{3} \mathrm{O}_{4} \text { by } \\
\text { melt-diffusion. }\end{array}$ & $\begin{array}{l}2 \\
0.05 \mathrm{~mA} \mathrm{~cm}^{-2}\end{array}$ & $\begin{array}{c}315(1700) \\
778(100)\end{array}$ & 15.4 & composite:AB:PVdF (70:20:10) \\
\hline & & & & & $712(100)$ & 24.7 & \\
\hline & & & & & 664 (100) & 34.9 & \\
\hline & & & & & $504(100)$ & 43.2 & \\
\hline $\mathrm{CoMoS}_{3.13}-\mathrm{SnO}_{2}$ & 73 & core-shell & $\begin{array}{c}\mathrm{CoMoS}_{3.13} \text { and } \mathrm{CoMoS}_{3.13 /} \mathrm{SnO}_{2} \text { by } \\
\text { hydrothermal method at } 140^{\circ} \mathrm{C} \text { and } 170^{\circ} \mathrm{C} \\
\text { respectively. }\end{array}$ & 0.3 & $718(50)$ & NR & $\begin{array}{l}\text { composite:graphite:CMC } \\
(70: 20: 10)\end{array}$ \\
\hline ZnO-sulfur & 74 & $\begin{array}{l}\text { carpet-like porous nanostructures } \\
\text { composed by } \mathrm{ZnO} \text { (hexagonal } \\
\text { wurtzite) nanoparticles }\end{array}$ & $\begin{array}{l}\mathrm{ZnO} \text { by hydrothermal process and heating } \\
\text { treatment at } 180^{\circ} \mathrm{C} \text { and } 600^{\circ} \mathrm{C} \text { respectively. } \\
\mathrm{S} / \mathrm{ZnO} \text { by melt-diffusion method. }\end{array}$ & 0.2 & $662(100)$ & NR & $\begin{array}{c}\text { composite:carbon black:PVdF } \\
\text { (80:10:10) }\end{array}$ \\
\hline $\mathrm{SiO}_{2}$-sulfur & 75 & $\begin{array}{l}\text { amorphous structure and smooth } \\
\text { morphology }\end{array}$ & $\mathrm{GPSiO}_{2} / \mathrm{S}$ via a melt-diffusion strategy. & 0.1 & $814(50)$ & 72 & composite:AB:PVdF (70:20:10) \\
\hline
\end{tabular}


with an increment of sulfur content. At a current density of $0.05 \mathrm{~mA}$ $\mathrm{cm}^{-2}$ and a $15.4 \mathrm{wt} \%$ sulfur content, $\mathrm{Co}_{3} \mathrm{O}_{4}-\mathrm{S}$ achieved a capacity retention of $778 \mathrm{~mA} \mathrm{~h} \mathrm{~g}^{-1}$ after 100 cycles.

Xue's group ${ }^{73}$ proposed the incorporation of $\mathrm{SnO}_{2}$ on the surface of a metal sulfide such as $\mathrm{CoMoS}_{3.13}$, where it was proposed that the metallic nanoparticles can enhance the conductivity. The authors observed that with the incorporation of a metal oxide, results improved due to the synergistic effect that takes place between the $\mathrm{SnO}_{2}$ and $\mathrm{CoMoS}_{3.13}$. Both composites, $\mathrm{CoMoS}_{3.13}$ and $\mathrm{CoMoS}_{3.13} / \mathrm{SnO}_{2}$ were prepared by a hydrothermal process involving reactions in aqueous and ethanol solutions and treated in autoclave. Core-shell structure composites were obtained. It is claimed that the $\mathrm{SnO}_{2}$ shell is responsible for trapping soluble polysulfides, restraining their diffusion and avoiding the loss of active material. Cathodes were prepared by mixing $\mathrm{CoMoS}_{3.13}-\mathrm{SnO}_{2}$ nanocomposites, conductive graphite and carboxymethyl cellulose with a weight ratio of 70:20:10. An initial discharge capacity of $964 \mathrm{~mA} \mathrm{~h} \mathrm{~g}^{-1}$ at $0.3 \mathrm{C}$ was achieved. Capacity retention of $718 \mathrm{~mA} \mathrm{~h} \mathrm{~g}^{-1}$ was reported after 50 cycles at the same rate.

Song et al. ${ }^{74}$ proposed the use of $\mathrm{ZnO}$ porous nanostructures combined with sulfur particles. $\mathrm{ZnO}$ compounds were prepared by hydrothermal process at $180^{\circ} \mathrm{C}$ for $20 \mathrm{~h}$ followed by calcination at $600^{\circ} \mathrm{C}$ for $2 \mathrm{~h}$. The $\mathrm{ZnO}-\mathrm{S}$ composite was synthetized by a melt-diffusion process at $155^{\circ} \mathrm{C}$ for $8 \mathrm{~h}$ using a tubular furnace under $\mathrm{Ar}$ atmosphere. By X-ray diffraction it is observed that sulfur particles are absorbed on the $\mathrm{ZnO}$ materials. For the electrochemical characterization, the composite cathode was prepared by mixing $80 \mathrm{wt} \% \mathrm{ZnO}-\mathrm{S}$ materials, $10 \mathrm{wt} \%$ conductive carbon black and $10 \mathrm{wt} \% \mathrm{PVdF}$ as a binder. An initial discharge capacity of $1414 \mathrm{~mA} \mathrm{~h} \mathrm{~g}^{-1}$ at $0.2 \mathrm{C}$ was achieved. Capacity retention of $662 \mathrm{~mA} \mathrm{~h} \mathrm{~g}^{-1}$ was obtained after 100 cycles.

Li's group reported gaseous-phase silica-coated sulfur particles $\left(\mathrm{GPSiO}_{2}\right)$ as a cathode material for lithium-sulfur batteries. ${ }^{75}$ The composites were synthesized through a melt-diffusion strategy. The mixtures of sulfur and $\mathrm{GPSiO}_{2}(7-40 \mathrm{nmm}$ size $)$ with different weight ratios were grounded and heated at $155^{\circ} \mathrm{C}$ for $8 \mathrm{~h}$ under argon gas. The composite with $72 \mathrm{wt} \%$ sulfur content achieved an initial specific capacity up to $1610 \mathrm{~mA} \mathrm{~h} \mathrm{~g}^{-1}$, and retained $814 \mathrm{~mA} \mathrm{~h} \mathrm{~g}^{-1}$ after 50 cycles $0.1 \mathrm{C}$.

Finally, it is important to highlight that when some of these oxides are used as host materials in sulfur batteries it is not to be discarded that lithium insertion takes places within the metal-oxide structure, ${ }^{69,71,72}$ following pretty much the same mechanisms as in classical lithiumion batteries. ${ }^{20}$ However, when this contribution has been purposely measured (i.e. in the absence of $\mathrm{S}$ ), results have shown that its contribution to the total capacity was minimal, e.g. a discharge capacity of $36 \mathrm{~mA} \mathrm{~h} \mathrm{~g}^{-1}$ at $335 \mathrm{~mA} \mathrm{~g}^{-1}$ for $\mathrm{TiO}_{2}$, being almost zero after 50 cycles, vs. $914 \mathrm{~mA} \mathrm{~h} \mathrm{~g}^{-1}$ for $\mathrm{TiO}_{2}-\mathrm{S}$ at same current density. ${ }^{69}$

A shorter list of publications on the use of metal oxides as host materials has been reported, standing out, amongst them, titanium and manganese oxides. These materials were synthesized most often as mesoporous structures, involving two synthetic steps: one for the preparation of the oxide, and the second one for the sulfur-oxide composite. Metal oxides act primarily as adsorbent agents. Their use allows for a homogeneous sulfur distribution, which is confined, together with polysulfides within the mesopores through electrostatic interactions and/or bonding that take place with the polar functional groups. The electrode architecture, for example hollow nanotubes and core-shell structures, also played an important role. Firstly, the generated void spaces allowed for a physical confinement of a larger amount of sulfur. Secondly, the diffusion and dissolution of polysulfides could be avoided, not only because of chemical adsorption by the metal oxide, but also from a physical confinement by the architecture, which makes for a more tortuous scape for the soluble compounds. Therefore, here the metal oxide functioned as a physical and chemical barrier.

\section{Sulfur-Polymer-Metal Oxide Composite Cathode Materials}

We have discussed how polymers display good conductivity and chemical stability, and how they can act as a protective layer to prevent dissolution of polysulfides avoiding active material loss. Furthermore, their mechanic properties are helpful to accommodate volume changes that occur during cell cycling. In turn, metal oxides have also been proposed to improve the performance of lithium sulfur cathodes. The porous structures of metal oxides host materials have been proved successful to produce a homogeneous dispersion of sulfur and the adsorption of polysulfides by strong electrostatic interactions, or strong chemical absorption, thus reducing the shuttle effect into the organic electrolyte. The mixing of polymeric materials and small amounts of metal oxides to prepare yet another type of sulfur cathode materials has been reported. It is usually claimed that the polymer offers good conductivity and a soft structure, while the oxide provides for a porous host structure and high surface area. The incorporation of a certain amount of metal oxide into a polymeric material, produces a ternary host material with higher specific surface area, than the original polymeric structure, allowing for the physical confinement of a larger amount of sulfur. ${ }^{68,70}$ Table III gathers the most important data of articles reporting the use of metal oxides in sulfur cathodes published since 2010 .

Chen's group proposed a ternary cathode made of S/PAN/ $\mathrm{Mg}_{0.6} \mathrm{Ni}_{0.4} \mathrm{O} .^{76}$ The $\mathrm{Mg}_{0.6} \mathrm{Ni}_{0.4} \mathrm{O}$ mix-oxide was synthetized via a self-propagating high temperature process. A viscous liquid was obtained by boiling of an aqueous solution of the metal salts. The synthesis continued by a self-sustained combustion, and finally a calcination at $700^{\circ} \mathrm{C}$ was carried out. The $\mathrm{S} / \mathrm{PAN} / \mathrm{Mg}_{0.6} \mathrm{Ni}_{0.4} \mathrm{O}$ ternary composite, with $38.5 \mathrm{wt} \%$ sulfur content, was prepared by mixing sulfur particles, polyacrylonitrile and metal oxide by ball milling followed by heat-treatment at $350^{\circ} \mathrm{C}$ for $3 \mathrm{~h}$. Structural changes on the S/PAN composite and an increase of the specific area of the material were reported after addition of the metal oxide, but no chemical reaction between the composite components was observed. While the S/PAN binary compound consists of agglomerated particles with a smooth surface, the $\mathrm{S} / \mathrm{PAN} / \mathrm{Mg}_{0.6} \mathrm{Ni}_{0.4} \mathrm{O}$ ternary composite consists of nanoparticles resulting in a rough surface. The $\mathrm{Mg}_{0.6} \mathrm{Ni}_{0.4} \mathrm{O}$ nanoparticles generate a 3D structure which could allow a better ionic diffusion. A high specific area, which is two times higher than that of the binary S/PAN, can improve the interaction between the electrode and the electrolyte. According to the authors, the addition of $\mathrm{Mg}_{0.6} \mathrm{Ni}_{0.4} \mathrm{O}$ suppresses the separation and agglomeration of active material in the composite, maintaining a homogeneous distribution of all components during the discharge-charge cycle. Overall, the stability and electrochemical performance of the cathode were enhanced. The electrochemical assays showed an initial discharge capacity of $1543 \mathrm{~mA} \mathrm{~h} \mathrm{~g}^{-1}$ at $0.1 \mathrm{C}$ and a capacity retention of approximately $1200 \mathrm{~mA} \mathrm{~h} \mathrm{~g}^{-1}$ after 100 cycles.

Two years later, Shearing et al., proposed two new ternary composite cathodes, produced by the combination of sulfur-polyaniline, with alternatively $\mathrm{Mg}_{0.6} \mathrm{Ni}_{0.4} \mathrm{O}$ or $\mathrm{Al}_{2} \mathrm{O}_{3}$ as oxide additives. ${ }^{77}$ The $\mathrm{S} / \mathrm{PANI} / \mathrm{Mg}_{0.6} \mathrm{Ni}_{0.4} \mathrm{O}$ and $\mathrm{S} / \mathrm{PANI} / \mathrm{Al}_{2} \mathrm{O}_{3}$ composites were synthetized by mixing sulfur particles, polyaniline and the corresponding oxide by wet ball milling, followed by a heat-treatment in two subsequent steps: at $160^{\circ} \mathrm{C}$ and $300^{\circ} \mathrm{C}$ under argon atmosphere. The addition of the metal oxide changes the morphology of the composites, resulting in irregular pores, a rough surface and higher specific surface area than the S/PANI binary compound. These changes provide a more facile ionic transport and charge transfer process. The addition of $\mathrm{Mg}_{0.6} \mathrm{Ni}_{0.4} \mathrm{O}$ produced more marked changes than that of $\mathrm{Al}_{2} \mathrm{O}_{3}$. For S/PANI/ $\mathrm{Mg}_{0.6} \mathrm{Ni}_{0.4} \mathrm{O}$, an initial discharge capacity of $1448 \mathrm{~mA} \mathrm{~h} \mathrm{~g}$ at $0.1 \mathrm{C}$ and a capacity retention of $772 \mathrm{~mA} \mathrm{~h} \mathrm{~g}^{-1}$ after 100 cycles were achieved. In turn, values of $1392 \mathrm{~mA} \mathrm{~h} \mathrm{~g}^{-1}$ at $0.1 \mathrm{C}$ and 612 $\mathrm{mA} \mathrm{h} \mathrm{g}{ }^{-1}$ after 100 cycles were reported for $\mathrm{S} / \mathrm{PANI} / \mathrm{Al}_{2} \mathrm{O}_{3}$. Upon cycling, the $\mathrm{S} / \mathrm{PANI} / \mathrm{Al}_{2} \mathrm{O}_{3}$ composite presented evidence of active material agglomeration suggesting its separation from the conductive agent, generating lower sulfur utilization and a rapid capacity loss. In contrast, the $\mathrm{S} / \mathrm{PANI} / \mathrm{Mg}_{0.6} \mathrm{Ni}_{0.4} \mathrm{O}$ composite did not change upon cycling. Therefore, it is suggested that the mixed-metal oxide prevents the active material agglomeration; it adsorbs the lithium polysulfides and preserves the higher conductivity of the sample. If we compare the proposed change from polyacrylonitrile ${ }^{76}$ to polyaniline, a lower capacity loss using polyaniline as a host material was observed. 


\begin{tabular}{|c|c|c|c|c|c|c|c|}
\hline Composite & {$[\operatorname{Ref}]$} & Morphology & Synthesis method & $\begin{array}{l}\text { Current } \\
\text { rate/density } \\
{[C]}\end{array}$ & $\begin{array}{l}\text { Capacity } \\
\text { retention } \\
{\left[\mathrm{mA} \mathrm{h}^{-1}\right]} \\
\left(\mathrm{n}^{\circ} \text { cycles }\right)\end{array}$ & $\begin{array}{l}\text { Sulfur } \\
\text { content } \\
{[\%]}\end{array}$ & Cathode composition [wt $\%$ ] \\
\hline $\mathrm{PPy}-\mathrm{TiO}_{2}$-sulfur & 78 & $\begin{array}{l}\text { coaxial heterogeneous } \\
\text { nanotubes }\end{array}$ & $\begin{array}{c}\mathrm{TiO}_{2} \text { by a two-step anodization method followed by } \\
\text { a heat-treatment at } 700^{\circ} \mathrm{C}, \mathrm{PPy}-\mathrm{TiO}_{2} \text { by } \\
\text { electrochemically depositing PPy on } \mathrm{TiO}_{2} \text {. } \\
\mathrm{S} / \mathrm{PPy} / \mathrm{TiO}_{2} \mathrm{NTs}-160 \text { and } \mathrm{S} / \mathrm{PPy} / \mathrm{TiO} \mathrm{NTs}_{2}-300 \text { by } \\
\text { heat-treatment at } 160^{\circ} \mathrm{C} \text { and } 300^{\circ} \mathrm{C} \text { respectively. }\end{array}$ & 0.1 & $\begin{array}{c}640(100) \\
1150(100)\end{array}$ & $\begin{array}{c}70.4 \\
64.68\end{array}$ & $\begin{array}{c}\text { No binder or conducting } \\
\text { agent }\end{array}$ \\
\hline $\begin{array}{l}\text { PEDOT- } \mathrm{MnO}_{2} \\
\text {-sulfur }\end{array}$ & 79 & core-shell nanospheres & $\begin{array}{l}\mathrm{S} \text { nanoparticles by adding concentrated } \mathrm{HCl} \text { to an } \\
\text { aqueous solution of } \mathrm{Na}_{2} \mathrm{~S}_{2} \mathrm{O}_{3} \text {. S@ PEDOT by in-situ } \\
\text { oxidative polymerization. S@PEDOT/MnO } \mathrm{Mn}_{2} \text { via } \\
\text { redox exchange of permanganate ions with the } \\
\text { functional group on PEDOT by facile soaking in } \\
\mathrm{KMnO}_{4} \text {. }\end{array}$ & $\begin{array}{l}0.2 \\
0.5\end{array}$ & $\begin{array}{l}827(200) \\
545(200)\end{array}$ & 87 & $\begin{array}{l}\text { composite:AB:PVdF } \\
\quad(75: 15: 10)\end{array}$ \\
\hline $\begin{array}{l}\text { PANI- } \mathrm{Al}_{2} \mathrm{O}_{3}- \\
\text { sulfur }\end{array}$ & 77 & agglomerated plate-like & $\begin{array}{l}\text { Via ball milling followed by heat-treatment in two } \\
\text { steps: at } 160^{\circ} \mathrm{C} \text { and } 300^{\circ} \mathrm{C} \text { under argon. }\end{array}$ & 0.1 & $612(100)$ & 41.6 & $\begin{array}{l}\text { composite:KB:PVdF } \\
(80: 10: 10)\end{array}$ \\
\hline $\begin{array}{l}\text { PANI- } \\
\mathrm{Mg}_{0.6} \mathrm{Ni}_{0.4} \mathrm{O}- \\
\text { sulfur }\end{array}$ & 77 & agglomerated plate-like & $\begin{array}{l}\mathrm{Mg}_{0.6} \mathrm{Ni}_{0.4} \mathrm{O} \text { by a self-propagating high temperature } \\
\text { synthesis method. PANI- } \mathrm{Mg}_{0.6} \mathrm{Ni}_{0.4} \mathrm{O} \text {-sulfur same } \\
\text { as PANI- } \mathrm{Al}_{2} \mathrm{O}_{3} \text {-sulfur. }\end{array}$ & 0.1 & $772(100)$ & 41.8 & $\begin{array}{l}\text { composite:KB:PVdF } \\
\quad(80: 10: 10)\end{array}$ \\
\hline $\begin{array}{l}\text { PAN- } \\
\mathrm{Mg}_{0.6} \mathrm{Ni}_{0.4} \mathrm{O}- \\
\text { sulfur }\end{array}$ & 76 & $\begin{array}{l}\text { agglomerated particles } \\
\text { resulting in irregular } \\
\text { pores and rougher } \\
\text { surfaces by addition of } \\
\mathrm{Mg}_{0.6} \mathrm{Ni}_{0.4} \mathrm{O}\end{array}$ & $\begin{array}{l}\mathrm{Mg}_{0.6} \mathrm{Ni}_{0.4} \mathrm{O} \text { via self-propagating method followed } \\
\text { by calcination at } 700^{\circ} \mathrm{C} \text {. S-PAN- } \mathrm{Mg}_{0.6} \mathrm{Ni}_{0.4} \mathrm{O} \text { via } \\
\text { ball milling followed by heat-treatment at } 350^{\circ} \mathrm{C} \text {. }\end{array}$ & 0.1 & $\sim 1200(100)$ & 38.5 & $\begin{array}{l}\text { composite:AB:PVdF } \\
\quad(80: 10: 10)\end{array}$ \\
\hline $\mathrm{PPy}-\mathrm{Al}_{2} \mathrm{O}_{3}$-sulfur & 26 & $\begin{array}{l}\text { hybrid material with } \\
\text { rough surface }\end{array}$ & $\begin{array}{l}\mathrm{S} / \mathrm{Al}_{2} \mathrm{O}_{3} \text { via ball milling and melt-diffusion process. } \\
\mathrm{S} / \mathrm{Al}_{2} \mathrm{O}_{3} / \mathrm{PPy} \text { via in situ oxidative polymerization. }\end{array}$ & 0.1 & $730(100)$ & 63 & $\begin{array}{l}\text { composite:AB: PVdF } \\
(70: 20: 10)\end{array}$ \\
\hline
\end{tabular}


Cairns et al. prepared a $\mathrm{S} / \mathrm{PPy} / \mathrm{TiO}_{2}$ ternary composite cathode. ${ }^{78}$ The $\mathrm{TiO}_{2}$ was obtained by two step anodization method using titanium foil as the working electrode and platinum foil as the counter electrode. Between two anodization steps, a heat-treatment at $700^{\circ} \mathrm{C}$ for $1 \mathrm{~h}$ was carried out. $\mathrm{PPy}-\mathrm{TiO}_{2}$ was prepared by electrochemically depositing pyrrole on $\mathrm{TiO}_{2}$ nanotubes in an aqueous pyrrole solution. For the final synthesis of $\mathrm{S} / \mathrm{PPy} / \mathrm{TiO}_{2}$, the sulfur loading was carried out from a $1 \%$ sulfur solution in toluene followed by heat-treatment. The sulfur content was approximately $70 \mathrm{wt} \%$, higher than the metal oxides-polymer-sulfur compounds synthetized by Chen's group, with a percentage of sulfur content around $40 \% .^{76}$ The composite material was directly used as a cathode without the addition of any conductive agent nor binder. A better stability in the $\mathrm{S} / \mathrm{PPy} / \mathrm{TiO}_{2}$ is observed with regards to $\mathrm{TiO}_{2}-\mathrm{S}$ cathode. ${ }^{78}$ According to the authors this is because in the ternary composite, the generated polysulfides can be better trapped into the polymeric structure by S-C chemical bonds. The temperature effect during the heating stage in the synthesis of the ternary composite was evaluated between $160^{\circ} \mathrm{C}$ and $300^{\circ} \mathrm{C}$. The $\mathrm{S} / \mathrm{PPy} / \mathrm{TiO}_{2}$ synthetized at $300^{\circ} \mathrm{C}$ showed the best electrochemical performance, achieving a capacity retention of $1150 \mathrm{~mA} \mathrm{~h} \mathrm{~g}^{-1}$ after 100 cycles at $0.1 \mathrm{C}$. At $300^{\circ} \mathrm{C}$, it is possible remove the surface sulfur and also the elemental sulfur predominate as $S_{6}$ and $S_{2}$ which have more extensive chemical bonds with PPy. Furthermore, it was noted that the capacity value after 100 cycles is higher than that for the first cycle. This is due to a fluctuation in the capacity values attributed to the catalytic action of polysulfides trapped into the nanotube arrays.

Jin et al. prepared a sulfur/alumina/polypyrrole $\left(\mathrm{S}_{\mathrm{Al}} \mathrm{Al}_{2} \mathrm{O}_{3} / \mathrm{PPy}\right)$ ternary material. ${ }^{26}$ The strong adsorption in $\mathrm{Al}_{2} \mathrm{O}_{3}$ decreases the dissolution of polysulfides, while the PPy coating works as a conductive and flexible additive. The $\mathrm{S} / \mathrm{Al}_{2} \mathrm{O}_{3}$ composite was synthesized firstly by mixing sublimed sulfur and $\mathrm{Al}_{2} \mathrm{O}_{3}$ by ball milling, followed by melt-diffusion method at $155^{\circ} \mathrm{C}$ for $12 \mathrm{~h}$. The $\mathrm{S} / \mathrm{Al}_{2} \mathrm{O}_{3} / \mathrm{PPy}$ composite was prepared via in situ polymerization of pyrrole using ferric chloride as an oxidant. The chemical process was carried out at $0-5^{\circ} \mathrm{C}$ for $12 \mathrm{~h}$. The hybrid composite, with a $63 \mathrm{wt} \%$ sulfur content, showed a good dispersion of $\mathrm{PPy}, \mathrm{Al}_{2} \mathrm{O}_{3}$ and sulfur. It manifested an initial discharge capacity of $1088 \mathrm{~mA} \mathrm{~h} \mathrm{~g}^{-1}$ and a discharge capacity of 730 $\mathrm{mA} \mathrm{h} \mathrm{g}{ }^{-1}$ after 100 cycles at $0.1 \mathrm{C}$. According to the authors, the synergy effect of $\mathrm{Al}_{2} \mathrm{O}_{3}$ and $\mathrm{PPy}$ gives rise a good electrochemical performance.

Su et al. reported the synthesis S@PEDOT core-shell nanospheres functionalized with $\mathrm{MnO}_{2}$ nanosheets. ${ }^{79}$ The sulfur nanoparticles (SNPs), with almost spherical shape and a rough surface, were synthetized by addition of concentrated $\mathrm{HCl}$ to an aqueous solution of $\mathrm{Na}_{2} \mathrm{~S}_{2} \mathrm{O}_{3}$ at room temperature. The S@PEDOT, with defined coreshell structure, was prepared by in situ oxidative polymerization of 3,4-ethylenedioxythiophene into the solution of sulfur nanoparticles. According to the authors, the flexible PEDOT layer grown on S-NPs will accommodate the volume expansion of sulfur during lithiation, improve the conductivity of the material and help avoid polysulfides dissolution. Finally, the $\mathrm{MnO}_{2}$ nanosheets were anchored onto the $\mathrm{S} @$ PEDOT surface via the redox exchange of permanganate ions with the functional groups on PEDOT by soaking in $\mathrm{KMnO}_{4}$ solution. The $\mathrm{S} @$ PEDOT/MnO 2 , with 87 wt \% sulfur content, keeps spherical shape with a $\mathrm{MnO}_{2}$ uniform layer. The rough surface of S@PEDOT/MnO provides high contact area allowing the wettability of the electrode with the electrolyte and a short diffusion pathway for Li ions and electron transport. The loss of active material is suppressed and the shuttle effect is reduced. As a result, an initial discharge capacity of $1150 \mathrm{~mA}$ $\mathrm{h} \mathrm{g}^{-1}$ at $0.2 \mathrm{C}$ was achieved, which remains at $827 \mathrm{~mA} \mathrm{~h} \mathrm{~g}^{-1}$ after 200 cycles at the same rate. The improved capacities, even at higher current rate (an initial capacity of $685 \mathrm{~mA} \mathrm{~h} \mathrm{~g}^{-1}$ and $360 \mathrm{~mA} \mathrm{~h} \mathrm{~g}^{-1}$ after 200 cycles at $1 \mathrm{C}$ ) suggest that the core-shell structure can help to encapsulate the polysulfides and mitigate capacity fading. This is the only S-polymer-metal oxide composite that was tested at high discharge current and for which more than 100 cycles have been shown. While the best capacity retention values were shown by $\mathrm{S}-\mathrm{PPy}-\mathrm{TiO}_{2}{ }^{78}$ and $\mathrm{S}-\mathrm{PAN}-\mathrm{Mg}_{0.6} \mathrm{Ni}_{0.4} \mathrm{O},{ }^{77}$ those cells were only tested at $0.1 \mathrm{C}$ and for 100 cycles. Conversely, S-PEDOT-MnO2 showed slightly lower capacity retention values, although these were measured up to $3 \mathrm{C}$, and successful cathodic activity was shown up to 200 cycles with most of the original capacity being conserved.

Overall, in ternary composites, researchers seek to potentiate the individual properties of both polymers and metal oxides. For the particular case where PAN was the polymer used, the oxide functioned not only as adsorbent agent but also generated changes in the morphology of the sulfur-polymer compound, with respect to the original structure of the binary compound (no metal oxide). With regards to synthesis methodology, when the ternary composite was prepared via ball milling, an agglomerated structure was obtained. Conversely, if the ternary compound was synthesized in two stages where a binary composite is first formed, a highly ordered final structure, such as core-shell or hollow nanotubes, was observed. On this last case, either the polymer or the metal oxide in the binary composite is the main host material for sulfur. While the other compound acts as a protective layer, ensuring that both sulfur and polysulfides, remain within the cathode.

\section{Other Composite Cathode Materials}

Beyond polymers and metal oxides, yet over dozen other compounds have been proposed as host materials which do not fall into either of the already described categories. Interestingly, several of these compounds display very high capacity retention and very promising chemical properties. Table IV gathers the most important data of articles reporting the use of metal oxides in sulfur cathodes published since 2010.

Liu et al. synthesized sulfur compounds with phosphazene groups: triphosphazene sulfide (PS) and nitroaniline-triphosphazene disulfide (NPS) ${ }^{80}$ With the objective of improving the cycling performance, the authors proposed to change the surface properties of sulfur particles from hydrophobic to hydrophilic, by modifying them with phosphazene groups, with the added advantage of reducing particle size. The solid PS compound was obtained by mixing under stirring and reflux solutions of $\mathrm{Na}_{2} \mathrm{~S}$ and $\mathrm{P}_{3} \mathrm{~N}_{3} \mathrm{Cl}_{6}$ in DMF. For the synthesis of NPS, 3-nitroaniline was mixed with $\mathrm{P}_{3} \mathrm{~N}_{3} \mathrm{Cl}_{6}$ and triethylamine in THF to obtain $\mathrm{Et}_{3} \mathrm{~N} \cdot \mathrm{HCl}$. By mixing the filtrate with $\mathrm{Na}_{2} \mathrm{~S}_{3}$, NPS was obtained. Except for filtration, all other steps were performed under a nitrogen atmosphere. These surface modifications generate compounds with a denser and rougher surface as compared to pristine sulfur, and with tiny pores which are useful for the absorption of electrolyte. In addition, the improved hydrophilicity generates a better electrode-electrolyte affinity. To evaluate the electrochemical properties, the cathodes were prepared by mixing $70 \mathrm{wt} \%$ PS or NPS, $20 \mathrm{wt} \%$ acetylene black and $10 \mathrm{wt} \%$ PVdF. The reported discharge capacities are promising, although they were measured at only $100 \mathrm{~mA}$ $\mathrm{g}^{-1}$ discharge current. Cyclability was shown only up to 22 cycles, after which PS capacity decreased to half the original value. Conversely, during the 22 cycles, the capacity of NPS showed an erratic behavior, with an overall tendency to decay, roughly to half the maximum value.

Dai et al. proposed a porous aromatic structure (PAF) as a cathode material for lithium-sulfur batteries. ${ }^{81}$ PAFs have high surface area, but low electrical conductivity; some authors argue that the physical confinement of sulfur species within a porous material is more important than the conductivity of said material for lithium-sulfur batteries. ${ }^{82}$ In fact, the overall cathode conductivity can be improved with the addition of a conductive agent. PAF was prepared via the Ullmann Yamamoto reaction of para-tribromotribenzyl aniline. The PAF-S compound was synthesized by the melt diffusion method at $155^{\circ} \mathrm{C}$, achieving a homogeneous distribution of sulfur within the pores of the aromatic compound structure. At a rate of $0.05 \mathrm{C}$ the PAF-S electrode showed a reversible capacity of $1083 \mathrm{~mA} \mathrm{~h} \mathrm{~g}^{-1}$ in the $\mathrm{LiPF}_{6}$-MiPS electrolyte, maintaining a capacity of $630 \mathrm{~mA} \mathrm{~h} \mathrm{~g}^{-1}$ after 50 cycles. When $\mathrm{LiPF}_{6}-\mathrm{MiPS}$ electrolyte was changed for an ionic liquid, a reversible capacity of $830 \mathrm{~mA} \mathrm{~h} \mathrm{~g}^{-1}$ and a capacity retention of $690 \mathrm{~mA} \mathrm{~h} \mathrm{~g}^{-1}$ after 50 cycles was reported.

Manthiram et al. proposed 3D sulfur-nickel foam cathodes (SNF cathodes) based on nickel foams which display a conductive and 


\begin{tabular}{|c|c|c|c|c|c|c|c|}
\hline Composite & [Ref] & Morphology & Synthesis method & $\begin{array}{l}\text { Current } \\
\text { rate/density } \\
{[C]}\end{array}$ & $\begin{array}{l}\text { Capacity } \\
\text { retention } \\
{\left[\mathrm{mA} \mathrm{h}^{-1}\right]} \\
\left(\mathrm{n}^{\circ} \text { cycles }\right)\end{array}$ & $\begin{array}{l}\text { Sulfur } \\
\text { content } \\
{[\mathrm{wt} \%]}\end{array}$ & Cathode composition [wt\%] \\
\hline $\begin{array}{l}\text { triphosphazene sulfide } \\
\text { (PS) }\end{array}$ & 80 & $\begin{array}{c}\text { tiny pore particles with denser } \\
\text { and rougher surface than pure } \\
\text { sulfur }\end{array}$ & $\begin{array}{l}\text { Nucleophilic substitution method. All } \\
\text { synthesis steps prior to filtration were } \\
\text { performed at the atmosphere of } \mathrm{N}_{2} \text {. }\end{array}$ & $100 \mathrm{~mA} \mathrm{~g}^{-1}$ & $\sim 750(20)$ & NR & $\begin{array}{c}\text { composite: } \mathrm{AB}: \mathrm{PVdF} \\
(70: 20: 10)\end{array}$ \\
\hline $\begin{array}{l}\text { nitroaniline- } \\
\text { triphosphazene disulfide } \\
\text { (NPS) }\end{array}$ & 80 & same as above & Same as above. & $100 \mathrm{~mA} \mathrm{~g}^{-1}$ & $\sim 400(20)$ & NR & $\begin{array}{l}\text { composite:AB:PVdF } \\
(70: 20: 10)\end{array}$ \\
\hline $\begin{array}{l}\text { 3D sulfur-nickel foam } \\
\text { (SNF) }\end{array}$ & 83 & highly flexible and porous foam & $\begin{array}{l}\text { pristine } S \text { by a precipitation method at room } \\
\text { temperature. The SNF cathodes by a facile } \\
\text { paste-absorption method. }\end{array}$ & 0.2 & $\sim 700(50)$ & 70 & $\begin{array}{c}\text { composite:Super P:PVdF } \\
(70: 20: 10)\end{array}$ \\
\hline $\mathrm{Cu}_{3} \mathrm{BiS}_{3}$-sulfur & 84 & $\begin{array}{l}\text { 3D flower-like balls composed of } \\
\text { misoriented and 2D thin } \\
\text { nanosheets }\end{array}$ & $\begin{array}{c}\mathrm{Cu}_{3} \mathrm{BiS}_{3} \text { by solvothermal method. } \\
\mathrm{Cu}_{3} \mathrm{BiS}_{3} / \mathrm{S} \text { via melt-diffusion method. }\end{array}$ & 0.2 & $487(100)$ & 80 & $\begin{array}{c}\text { composite: } \mathrm{AB}: \mathrm{PVdF} \\
(80: 10: 10)\end{array}$ \\
\hline $\mathrm{MoS}_{2}$-sulfur & 85 & $\begin{array}{l}\text { MoS2 inclusions in a sulfur } \\
\text { matrix }\end{array}$ & $\begin{array}{l}\text { Sulfur/MoS } \mathrm{Mos}_{2} \text { beating of a mixture of } \\
\mathrm{MoS}_{2} \text { and sulfur to induce thermal } \\
\text { ring-opening polymerization. }\end{array}$ & 0.2 & $325(1000)$ & 50 & $\begin{array}{l}\text { composite:conductive } \\
\text { carbon:PE }(75: 20: 5)\end{array}$ \\
\hline $\begin{array}{l}\text { porous aromatic } \\
\text { framework-sulfur } \\
\text { (PAF-S) }\end{array}$ & 81 & porous aromatic framework & $\begin{array}{l}\text { PAF via Yamamoto-type Ullmann reaction } \\
\text { of para-tribromo-tribenzyl aniline. PAF-S by } \\
\text { melt diffusion. }\end{array}$ & 0.05 & $630(50)$ & 32 & $\begin{array}{l}\text { composite:carbon } \\
\text { black:PVdF }(65: 20: 15)\end{array}$ \\
\hline $\mathrm{Ti}_{2} \mathrm{C}$-sulfur & 86 & delaminated sheets & $\begin{array}{c}\mathrm{Ti}_{2} \mathrm{C} \text { by hydrofluoric acid treatment of } \\
\mathrm{Ti}_{2} \mathrm{AlC} \text { followed by a delamination in } \\
\text { DMSO. }\end{array}$ & 0.5 & $723(650)$ & 70 & $\begin{array}{c}\text { composite:Super P:PVdF } \\
(80: 10: 10)\end{array}$ \\
\hline $\begin{array}{l}\text { sulfur-metal cotton } \\
\text { (S-MC) }\end{array}$ & 87 & $\begin{array}{l}\text { interlaced wire-type and porous } \\
\text { 3D multilayer surfaces }\end{array}$ & $\begin{array}{l}\text { MC sprinkled, previously cleaned with } \mathrm{HCl} \\
\text { and S power grinded. S@MC by heating of a } \\
\text { mixture of MC:S in a vacuum oven. }\end{array}$ & 0.1 & $480(155)$ & NR & NR \\
\hline $\begin{array}{l}\text { sulfur- metal-organic } \\
\text { polyhedron (S-MOP) }\end{array}$ & 91 & $\begin{array}{l}\text { sulfur nanoparticles encapsulated } \\
\text { into MOP with polyhedral shape, } \\
\text { smooth surface and fine }\end{array}$ & $\begin{array}{l}\text { sulfur nanoparticles synthesized by a liquid } \\
\text { phase precipitation method. S@MOP via a } \\
\text { template method. }\end{array}$ & 0.2 & $\begin{array}{l}730(1000) \\
710(1000) \\
780(1000)\end{array}$ & $\begin{array}{l}24 \\
21 \\
32\end{array}$ & $\begin{array}{c}\text { No binder or conducting } \\
\text { agent }\end{array}$ \\
\hline $\begin{array}{l}\mathrm{Co}(\mathrm{OH})_{2} \text {-layered double } \\
\text { hydroxides-sulfur } \\
\text { (CH-LDH-S })\end{array}$ & 88 & $\begin{array}{c}\text { cristallinity. } \\
\text { double-shell structured } \\
\text { nanocages }\end{array}$ & $\begin{array}{c}\text { ZIF-67@LDH by reaction of ZIF-67 } \\
\text { particles with } \mathrm{Ni}\left(\mathrm{NO}_{3}\right)_{2} \text { in ethanol. } \\
\text { CH@LDH by reaction between } \\
\text { ZIF-67@LDH and } \mathrm{Na}_{2} \mathrm{MoO}_{4} \text {. Finally, } \\
\text { CH@LDH/S by a melting-diffusion method. }\end{array}$ & $\begin{array}{l}0.1 \\
0.5\end{array}$ & $\begin{array}{l}780(1000) \\
653(100) \\
491(100)\end{array}$ & $\begin{array}{l}32 \\
75\end{array}$ & $\begin{array}{c}\text { composite:Super } \\
\text { P:CNTs:PVdF (70:10:10:10) }\end{array}$ \\
\hline sulfur-TiN & 90 & $\begin{array}{l}\text { mesoporous small particles and } \\
\text { macroporous agglomeration }\end{array}$ & $\begin{array}{l}\text { TiN by solid-solid separation method with } \\
\mathrm{Zn}\left(\mathrm{TiO}_{3}\right) \text { precursor heated at } 900^{\circ} \mathrm{C} \text { under } \\
\text { ammonia gas. TiN-S by melt-diffusion } \\
\text { method. }\end{array}$ & 0.5 & $644(500)$ & 58.8 & $\begin{array}{c}\text { composite:Super } \\
\text { carbon:PVdF }(85: 5: 10)\end{array}$ \\
\hline sulfur- $\mathrm{Na}_{2} \mathrm{Fe}\left[\mathrm{Fe}(\mathrm{CN})_{6}\right]$ & 92 & nanocube architecture & $\begin{array}{c}\mathrm{Na}_{2} \mathrm{Fe}\left[\mathrm{Fe}(\mathrm{CN})_{6}\right] \text { via solution method with } \\
\text { heat-treatment. } \mathrm{S} @ \mathrm{Na} 2 \mathrm{Fe}\left[\mathrm{Fe}(\mathrm{CN})_{6}\right] \text { via a } \\
\text { liquid diffusion process. }\end{array}$ & 1 & $370(100)$ & $\sim 82$ & $\begin{array}{c}\text { composite: } \mathrm{AB}: \mathrm{PVdF} \\
(80: 10: 10)\end{array}$ \\
\hline $\begin{array}{c}\text { sulfur- } \mathrm{Na}_{2} \mathrm{Fe}\left[\mathrm{Fe}(\mathrm{CN})_{6}\right]- \\
\text { PEDOT }\end{array}$ & 92 & nanocube architecture & $\begin{array}{c}\mathrm{S} @ \mathrm{Na}_{2} \mathrm{Fe}\left[\mathrm{Fe}(\mathrm{CN})_{6}\right] @ \mathrm{PEDOT} \text { by one-step } \\
\text { polymerization process. }\end{array}$ & 1 & $770(100)$ & $\sim 80$ & $\begin{array}{c}\text { composite:AB:PVdF } \\
(80: 10: 10)\end{array}$ \\
\hline $\mathrm{Co}_{4} \mathrm{~N} @ \mathrm{~S}$ & 93 & $\begin{array}{l}\text { nanosheets assembled } \\
\text { mesoporous sphere }\end{array}$ & $\begin{array}{c}\mathrm{Co}_{3} \mathrm{O}_{4} \text { via precipitation method in solution. } \\
\mathrm{Co}_{4} \mathrm{~N} \text { via heat-treatment of } \mathrm{Co}_{3} \mathrm{O}_{4} \text { in } \\
\text { ammonia atmosphere. } \mathrm{Co}_{4} \mathrm{~N} / \mathrm{S} \text { via } \\
\text { melt-diffusion method. }\end{array}$ & $\begin{array}{c}0.5 \\
1\end{array}$ & $\begin{array}{l}1100(100) \\
1000(100)\end{array}$ & 72.3 & $\begin{array}{l}\text { composite:Super P:LA } \\
\text { (70:20:10) }\end{array}$ \\
\hline
\end{tabular}


porous microstructure improving its contact with the active material. ${ }^{83}$ The SNF cathodes with $70 \mathrm{wt} \%$ sulfur content were prepared by a paste-absorption method. Firstly, a paste is prepared by mixing sulfur, black carbon as conductive agent and PVdF as binder agent in a weight ratio 70:20:10 respectively. Then, the as-prepared paste is covered by a Ni foam disk and subjected to pressure to ensure even coverage. The nickel matrices have a ductile strip-like framework and an uneven surface providing abundant porous space. In addition, it has a highly flexible interwoven structure. The porous spaces and the surface of the $\mathrm{Ni}$ foams can hold sulfur by suppressing the loss of the active material and absorbing polysulfides. A good cycling performance was obtained by the above mentioned structural characteristics. At $0.2 \mathrm{C}$ a discharge capacity of $720 \mathrm{~mA} \mathrm{~h} \mathrm{~g}^{-1}$ was achieved. Most interestingly, a capacity retention close to $100 \%$ after 50 cycles was reported. Furthermore, the material significantly suppresses self-discharge problems, related to the physical properties of current collectors and their ability to protect sulfur cathodes.

The $\mathrm{Cu}$-Bi-S alloys are members of the copper-based multicomponent chalcogenide's family. They are formed by different stoichiometric ratios of their components, which are stable at room temperature, earth-abundant and inexpensive elements. $\mathrm{Lu}$ et al. chose $\mathrm{Cu}_{3} \mathrm{BiS}_{3}$ for the synthesis of a novel $\mathrm{Cu}_{3} \mathrm{BiS}_{3} / \mathrm{S}$ cathode material. ${ }^{84}$ The synthetic procedure consisted in dissolving $\mathrm{CuCl}_{2}, \mathrm{BiCl}_{3}$ and thiourea in ethanol and glycerol under stirring. The mixture was sealed into a Teflon-lined stainless steel autoclave, and heated to $180^{\circ} \mathrm{C}$ for $12 \mathrm{~h}$. Finally, the precipitate was filtrated, washed and dried at $80^{\circ} \mathrm{C}$. The $\mathrm{Cu}_{3} \mathrm{BiS}_{3} / \mathrm{S}$ composite was prepared via a melt-diffusion method at $155^{\circ} \mathrm{C}$ for 12 h. A quite complex 3D structure results from this synthetic process: 2D thin nanosheets are further arranged into 3D flower-like spheres. According to the authors, these structures have good adsorption characteristic, which improve cycle and rate performance. Cathodes were prepared by mixing composite, acetylene black and PVdF in weight ratio of 80:10:10 respectively. At a current rate of $0.2 \mathrm{C}$, a reversible capacity of $1343 \mathrm{~mA} \mathrm{~h} \mathrm{~g}^{-1}$ was obtained. At that same rate, and after 100 cycles, a capacity retention of $487 \mathrm{~mA} \mathrm{~h} \mathrm{~g}^{-1}$ still remained.

Pyun et al. reported the preparation and electrochemical characteristics of sulfur/MoS 2 (MolyS) composites. ${ }^{85}$ The in situ synthesis consisted in a scalable, one-pot process. 2D-sheets of $\mathrm{MoS}_{2}$ were dispersed in molten elemental sulfur heating above the melting temperature of sulfur with vigorous stirring. A composition study of different composites, designated as MolyS, with varying $\mathrm{MoS}_{2}$ loading from $10-50 \mathrm{wt} \%$ was performed. The best performance was observed with higher $\mathrm{MoS}_{2}$ loading. At $0.2 \mathrm{C}$ a reversible capacity of $1260 \mathrm{~mA} \mathrm{~h} \mathrm{~g}^{-1}$ was achieved. An impressive cyclability of 1000 cycles was reported, with a capacity retention of $325 \mathrm{~mA} \mathrm{~h} \mathrm{~g}^{-1}$. Furthermore, an enhanced rate capability was observed. According to the authors, this is due to the binding of the soluble higher order polysulfides to the $\mathrm{MoS}_{2}$ inclusions.

Nazar et al. proposed $\mathrm{Ti}_{2} \mathrm{C}$ as a host material. ${ }^{86}$ This compound belongs to the family of the MXenes, carbides or carbonitrides of early transition metals. These are obtained as exfoliated sheets from the treatment with HF of MAX phases, where M is a transition metal, $\mathrm{A}$ is an element of group IIIA or IVA and X is carbon and / or nitrogen. Nazar et al. used $\mathrm{Ti}_{2} \mathrm{AlC}$ as MAX phase, where $\mathrm{Al}$ is replaced by oxygenated functional groups, $\mathrm{OH}^{-}$, then $\mathrm{e}-\mathrm{Ti}_{2} \mathrm{C}$ (exfoliated carbide) was obtained. The delamination of $2 \mathrm{D} \mathrm{e}-\mathrm{Ti}_{2} \mathrm{C}$ nanosheets, to prepare $\mathrm{d}-\mathrm{Ti}_{2} \mathrm{C}$ (delaminated carbide), was carried out with DMSO. MXenes are generally characterized by having high intrinsic conductivity and a highly active two-dimensional surface. Surface hydroxyl groups may be replaced by elemental sulfur or polysulfide species. The S-Ti bond that takes place helps to establish a strong interaction between polysulfides and the host material, decreasing their dissolution. The $\mathrm{S} / \mathrm{d}-\mathrm{Ti}_{2} \mathrm{C}$ and $\mathrm{S} / \mathrm{e}-\mathrm{Ti}_{2} \mathrm{C}$ compounds were synthesized from the melt-diffusion method. A better dispersion and retention of sulfur for the composite synthetized from delaminated carbide were observed. Thus, a composite with a $70 \mathrm{wt} \%$ sulfur content was obtained. The composition of the final electrode was $80 \mathrm{wt} \% \mathrm{~S} / \mathrm{Ti}_{2} \mathrm{C}, 10 \mathrm{wt} \%$ Super $\mathrm{P}$ and 10 wt $\%$ PVdF. Electrochemical tests showed an initial discharge capac- 
ity of $1090 \mathrm{~mA} \mathrm{~h} \mathrm{~g}^{-1}$ at a rate of $0.5 \mathrm{C}$. For a higher rate, $1 \mathrm{C}$, the discharge capacity was still impressively close, at $1000 \mathrm{~mA} \mathrm{~h} \mathrm{~g}^{-1}$. Most interestingly, at $0.5 \mathrm{C}$, a capacity retention of $723 \mathrm{~mA} \mathrm{~h} \mathrm{~g}^{-1}$ was achieved after 650 cycles. Although the comparison of results with other materials is not straightforward, because there is no agreement on discharge rate, numbers of cycles and sulfur contents, these discharge capacity and capacity retention values make this material one of the best that has so far been reported as cathode for lithium-sulfur batteries. Surprisingly, these materials neither display a high surface area, nor a highly ordered porous structure. However, they effectively perform as sulfur host materials for lithium-sulfur batteries because there is a chemical interaction between the active material and the surface active sites of the host compound.

Ma et al. developed a 3D porous composite named S@MC, where MC stands for metal cotton. ${ }^{87}$ The MC was composed of stainless steel containing $\mathrm{Fe}-\mathrm{Cr}-\mathrm{Ni}-\mathrm{C}$ and has an interlaced wire-type structure with an irregular surface providing large porous void spaces. This allows the absorption of sulfur, the retention of polysulfides and electron transport, thereby improving the conductivity of the cathode. Its structure is also highly flexible allowing to accommodate the volume changes of the active material that occur during cycling process. The sample S@MC was prepared by homogeneous sprinkling sulfur on the surface of the metal structure followed by heating in a vacuum oven at $100^{\circ} \mathrm{C}$. An initial discharge capacity of $921 \mathrm{~mA} \mathrm{~h} \mathrm{~g}^{-1}$ was observed for a rate of $0.1 \mathrm{C}$. At the same rate, a capacity retention of $491 \mathrm{~mA} \mathrm{~h} \mathrm{~g}^{-1}$ was measured after 25 cycles. Interestingly, despite the initial fast capacity lost, a relatively high cycling stability was observed, with about $480 \mathrm{~mA} \mathrm{~h} \mathrm{~g}^{-1}$ after 155 cycles.

The double-shell $\mathrm{Co}(\mathrm{OH})_{2} / \mathrm{LDH}$ nanocages (denoted as CH@LDH), where LDH stands for layered double hydroxides, have been reported as sulfur host material by Lou et al. ${ }^{88}$ This is the first report incorporating LDHs, which are a class of anionic clays with $\left[\mathrm{M}^{2+}{ }_{1-\mathrm{x}} \mathrm{M}^{3+}{ }_{\mathrm{x}}(\mathrm{OH})_{2}\right]\left[\mathrm{A}^{\mathrm{n}-}{ }_{\mathrm{x} / \mathrm{n}}\right]^{*} \mathrm{mH}_{2} \mathrm{O}$ as general formula where $\mathrm{M}^{2+}$ and $\mathrm{M}^{3+}$ are divalent and trivalent cations respectively and $\mathrm{A}^{\mathrm{n}-}$ is a charge-balancing interlayer anion. The LDH shells, that might be expressed as $\left[\mathrm{Ni}^{2+}{ }_{1 / 3} \mathrm{Co}^{3+}{ }_{2 / 3}(\mathrm{OH})_{2}\right]\left[\mathrm{NO}_{3}{ }^{2-}{ }_{1 / 3}\right]^{*} \mathrm{mH}_{2} \mathrm{O}$, were formed on polyhedral ZIF-67 (zeolitic imidazolate framework-67) particles by reacting with $\mathrm{Ni}\left(\mathrm{NO}_{3}\right)_{2}$. The ZIF-67 particles were used as sacrificial templates and source of cobalt ions. Thus, the ZIF-67@LDH is obtained. Then, CH@LDH is prepared from the ZIF-67@LDH by reacting with a $\mathrm{Na}_{2} \mathrm{MoO}_{4}$ solution. Finally, the $\mathrm{S}$ is encapsulated homogeneously within the CH@LDH shells by a melt diffusion process at $155^{\circ} \mathrm{C}$ for $12 \mathrm{~h}$. The complex shell structure observed for the CH@LDH composite, a hollow polyhedron with outer LDH and inner $\mathrm{Co}(\mathrm{OH})_{2}$; allows for the encapsulation of a large amount of sulfur $(75 \mathrm{wt} \%)$. Moreover, it provides a functional surface (abundant hydrophilic hydroxyl groups) that allows chemical bonding with polysulfides (easy anion exchange capability in the interlayers) and avoid their dissolution in the electrolyte and subsequent diffusion out of the cathode material. In the electrochemical cycling performance evaluations an initial discharge capacity of $1014 \mathrm{~mA} \mathrm{~h} \mathrm{~g}^{-1}$ was obtained at $0.1 \mathrm{C}$. A capacity retention of $653 \mathrm{~mA} \mathrm{~h} \mathrm{~g}^{-1}$ was observed after 100 cycles. At a rate of $0.5 \mathrm{C}$, an initial capacity of $747 \mathrm{~mA}$ $\mathrm{h} \mathrm{g}^{-1}$ is achieved and at the same rate a capacity of $491 \mathrm{~mA} \mathrm{~h} \mathrm{~g}^{-1}$ after 100 cycles is maintained. The results are good if one takes into account the high sulfur content of the compound, i.e. overall performance of the cell. According to the authors, the good electrochemical performance is firstly attributed to the hollow structure of the compound which provides sufficient void space to accommodate a high amount of active material. Second, the polar nature of the surface, due to the presence of oxygenated functional groups, which allow a strong chemical interaction between the electrode material and the polysulfides decreasing the dissolution of these in the organic electrolyte. And third, the CH@LDH host material improves electrode reaction kinetics because the LDHs have catalytic properties, ${ }^{89}$ resulting in high rates properties even with a high sulfur content material.

Goodenough et al. synthesized a mesoporous TiN from a solidsolid phase separation method with zinc titanate as the precursor. The TiN-S compound was prepared from the melt diffusion method at $155^{\circ} \mathrm{C}$ for $12 \mathrm{~h} .{ }^{90}$ The decrease in the specific area and pore volume of TiN after sulfur loading, confirm that the sulfur particles were effectively introduced into the pores of the pristine material. The sulfur content in the compound is $58.8 \mathrm{wt} \%$. The formation of a passivation layer takes place on the material, which plays an important role in the confinement of sulfur and polysulfides by chemical interactions. According to the authors, a strong N-S interaction is established, with the formation of covalently bounded structures. At a rate of $0.5 \mathrm{C}$ the electrode delivers an initial discharge capacity of $988 \mathrm{~mA} \mathrm{~h} \mathrm{~g}^{-1}$. After 500 cycles, an impressive capacity retention of $644 \mathrm{~mA} \mathrm{~h} \mathrm{~g}^{-1}$ is observed. The excellent results were attributed to the ability of the host material to encapsulate sulfur and polysulfides inside pores by both chemical and physical interaction. In addition, a space between particles is observed which allows good penetration of the liquid electrolyte.

Zhao et al. used metal-organic polyhedrons (MOP) to encapsulated polyvinylpyrrolidone (PVP) covered sulfur nanoparticles. ${ }^{91}$ Three representative MOPs, i.e., ZIF-8, ZIF-67 and HKUST-1 were used for the synthesis of S@MOP via a template method. Firstly, sulfur nanoparticles were functionalized with PVP which not only stabilizes them, but also controls the shape and size of the hybrids. The encapsulation process depends on the starting MOP. For example, if ZIF-8 is used to prepare S @ZIF-8, zinc nitrate, 2-methylimidazole, PVP-coated sulfur nanoparticles need to be added to PVP solution under stirring, while maintaining it at room temperature without stirring. In summary, S@ZIF-8, S@ZIF-67 and S@HKUST-1 with 24 wt\%, 21 $\mathrm{wt} \%$ and $32 \mathrm{wt} \%$ sulfur contents, respectively were synthesized. Similar results for capacity retentions were observed for all three cases, and most importantly capacity retention values for 1000 cycles was reported. A slightly higher capacity retention value of $780 \mathrm{~mA} \mathrm{~h} \mathrm{~g}^{-1}$ at $0.2 \mathrm{C}$ was reported for S@HKUST-1. According to the authors, the MOPs incorporation can well confine the sulfur nanoparticles giving rise to higher structural stability to endure longer treatment period. This is one of the extremely few reports that show experimental data for such an impressive number of cycles, and the only one for which almost half of the theoretical maximum capacity for $\mathrm{S}$ is observed after that amount of cycles. It should however be said, that the sulfur content of these compounds did not exceed $32 \%$ wt in the highest case.

Taking into account the Lewis base behavior presented by polysulfides, Wang et al. ${ }^{92}$ hypothesized that the use of a host material that acts as a Lewis acid, such as Prussian Blue Analogues (PBAs), could result in a good strategy to improve polysulfide confinement. In this context, the use of sodium iron cyanide $\left(\mathrm{Na}_{2} \mathrm{Fe}\left[\mathrm{Fe}(\mathrm{CN})_{6}\right]\right)$ was proposed, and the compound $\mathrm{S} @ \mathrm{Na}_{2} \mathrm{Fe}\left[\mathrm{Fe}(\mathrm{CN})_{6}\right] @$ PEDOT was synthesized and tested. $\mathrm{Na}_{2} \mathrm{Fe}\left[\mathrm{Fe}(\mathrm{CN})_{6}\right]$ was prepared by mixing a $\mathrm{Fe}\left(\mathrm{NO}_{3}\right)_{2}$ aqueous solution and $\mathrm{PVP} / \mathrm{Na}_{2} \mathrm{Fe}\left[\mathrm{Fe}(\mathrm{CN})_{6}\right]$ solution in $\mathrm{HCl}$ under stirring and heating at $80^{\circ} \mathrm{C}$ for $24 \mathrm{~h}$. The as obtained blue precipitate was washed with water/ethanol and dried in vacuum at $80^{\circ} \mathrm{C}$ for 12 h. S@ $\mathrm{Na}_{2} \mathrm{Fe}\left[\mathrm{Fe}(\mathrm{CN})_{6}\right]$ was synthesized by a liquid diffusion process where the $\mathrm{Na}_{2} \mathrm{Fe}\left[\mathrm{Fe}(\mathrm{CN})_{6}\right]$ powder was dispersed in a $\mathrm{CS}_{2}$ solution under stirring. The compound was again washed with water/ethanol and dried in vacuum at $60^{\circ} \mathrm{C}$ for $5 \mathrm{~h}$. Finally, a solution with $\mathrm{S} @ \mathrm{Na}_{2} \mathrm{Fe}\left[\mathrm{Fe}(\mathrm{CN})_{6}\right]$ and EDOT monomer was prepared and kept in an ice bath under stirring. Ferric chloride was used as oxidizing and polymerizing agent. The precipitate was filtered and washed with water and finally dried at $100^{\circ} \mathrm{C}$ for $6 \mathrm{~h}$. For $\mathrm{S} @ \mathrm{Na}_{2} \mathrm{Fe}\left[\mathrm{Fe}(\mathrm{CN})_{6}\right.$ ], with $80 \mathrm{wt} \%$ content sulfur, a capacity retention of $370 \mathrm{~mA} \mathrm{~h} \mathrm{~g}^{-1}$ at $1 \mathrm{C}$ after 100 cycles was obtained. While, for the $\mathrm{S} @ \mathrm{Na}_{2} \mathrm{Fe}\left[\mathrm{Fe}(\mathrm{CN})_{6}\right] @ P E D O T$ composite, a capacity retention of $770 \mathrm{~mA} \mathrm{~h} \mathrm{~g}^{-1}$ at $1 \mathrm{C}$ after 100 cycles was achieved. The layer of positively charged PEDOT chains interact with the negatively charged sulfur species. In addition, it facilitates the diffusion of the $\mathrm{Li}^{+}$ions, and prevents the dissolution of polysulfides.

Cobalt nitride, $\mathrm{Co}_{4} \mathrm{~N}$, was proposed as a host material by Dong et al. ${ }^{93}$ In comparison with cobalt oxide, $\mathrm{Co}_{3} \mathrm{O}_{4}, \mathrm{Co}_{4} \mathrm{~N}$ showed a higher affinity for polysulfides and a stronger capacity for polysulfide adsorption. $\mathrm{Co}_{3} \mathrm{O}_{4}$ was obtained by calcination of a precursor, prepared from a solution of $\mathrm{Co}\left(\mathrm{CH}_{3} \mathrm{COO}\right)_{2}$ and PVP in ethylene gly- 
col, at $550^{\circ} \mathrm{C}$ for $4 \mathrm{~h} . \mathrm{Co}_{4} \mathrm{~N}$ was obtained by a thermal treatment of $\mathrm{Co}_{3} \mathrm{O}_{4}$ at $400^{\circ} \mathrm{C}$ for $4 \mathrm{~h}$ in ammonia atmosphere. The $\mathrm{Co}_{4} \mathrm{~N} / \mathrm{S}$ composite with a $72.3 \mathrm{wt} \%$ sulfur content was prepared by the melt-diffusion method, by mixing mesoporous $\mathrm{Co}_{4} \mathrm{~N}$ spheres and elemental sulfur, grinding and heating this mixture at $155^{\circ} \mathrm{C}$ for $6 \mathrm{~h}$. An initial discharge capacity of $1280 \mathrm{~mA} \mathrm{~h} \mathrm{~g}^{-1}$ is obtained at $1 \mathrm{C}$. While a capacity retention of $1000 \mathrm{~mA} \mathrm{~h} \mathrm{~g}^{-1}$ is achieved after 100 cycles at the same rate. This value represents the highest capacity retention measured at this high discharge rate amongst all the reports summarized here. Moreover, with $72.3 \mathrm{wt} \%, \mathrm{Co}_{4} \mathrm{~N} / \mathrm{S}$ contains amongst the highest $\mathrm{S}$ percentages reported here. The $\mathrm{Co}_{4} \mathrm{~N} / \mathrm{S}$ structure was reported to comprised nanosheets assembled into $3 \mathrm{D}$ mesoporous spheres with high specific area and a large pore volume. This nanostructure, together with the strong and rapid adsorption capacity of $\mathrm{Co}$ and $\mathrm{N}$ with $\mathrm{S}$ compounds and $\mathrm{Li}^{+}$contributed to an excellent electrochemical performance.

A new cathode material using the RANEY nickel was reported by Shan et al. ${ }^{94}$ The sulfur/RANEY nickel composite (S/RN) was synthesized by adding RANEY nickel to a solution of sulfur in THF, and sonicating. A cathode prepared with a $36.6 \mathrm{wt} \%$ sulfur displayed an initial discharge capacity of $1469 \mathrm{~mA} \mathrm{~h} \mathrm{~g}^{-1}$ at $0.5 \mathrm{C}$, maintaining a value of $758 \mathrm{~mA} \mathrm{~h} \mathrm{~g}^{-1}$ after 200 cycles. According to the authors, the results are attributed to the micro-mesopore structure of the composite where the sulfur is not only immobilized by physical adsorption but also by a reaction between sulfur and nickel that takes place by means of the formation of Lewis acid-base-like bonding. In addition, the small amount of $\mathrm{Ni}_{\mathrm{x}} \mathrm{Al}_{\mathrm{y}} \mathrm{O}_{\mathrm{z}}$ detected in the RANEY nickel has the ability to chemically absorb polysulfides, in the same way as other metal oxides. Furthermore, the authors evaluated the effect of the sulfur content on the cathode. A decrease in specific capacity with the increase in sulfur loading was found. Thus, under the same discharge conditions, for an S/RN compound with a $50 \mathrm{wt} \%$ sulfur content, an initial discharge capacity of $1002 \mathrm{~mA} \mathrm{~h} \mathrm{~g}^{-1}$ was obtained, and a value of $510 \mathrm{~mA} \mathrm{~h} \mathrm{~g}^{-1}$ remained after 200 cycles.

Zheng et al. proposed the use of $\mathrm{MoS}_{2}$ to encapsulate sulfur nanoparticles. ${ }^{95}$ Therefore, the $\mathrm{MoS}_{2}$-encapsulated hollow sulfur sphere composite was synthesized. Firstly, sulfur particles were prepared from a solution of sodium thiosulfate mixed with polyvinylpyrrolidone (PVP), under stirring and by addition of small amounts of $\mathrm{HCl}$. Then an aqueous dispersion of the as-obtained product was prepared. Also a dispersion of $\mathrm{MoS}_{2}$ was prepared by forced hydration of lithium intercalated $\mathrm{MoS}_{2}$ (by mixing $\mathrm{MoS}_{2}$ crystals and butyllithium solution) assisted by sonication. Thus, both suspensions were mixed, and the resulting product is filtered and washed with water/methanol. The high flexibility and the void spaces that are formed between the different components of the material ensure its structural integrity during the volume changes that take place under cycling. In addition, an interaction by van der Waals forces takes place between the sulfur particles and $\mathrm{MoS}_{2}$ allowing an effective encapsulation. An initial discharge capacity of $1137 \mathrm{~mA} \mathrm{~h} \mathrm{~g}^{-1}$ at $0.5 \mathrm{C}$ is obtained and a capacity retention above $900 \mathrm{~mA} \mathrm{~h} \mathrm{~g}^{-1}$ after 100 cycles is observed.

Sun et al. proposed the use of nickel phosphide yolk-shell $\left(\mathrm{Ni}_{2} \mathrm{P}\right.$ YS), as a new conductive host material. The authors proposed the synthesis of a novel nickel phosphide yolk-shell nanosphere encapsulated sulfur compound ( $\left.\mathrm{S} @ \mathrm{Ni}_{2} \mathrm{P}-\mathrm{YS}\right)$, following the strategy of using polar host materials to form strong chemical bonds with the polar sulfur species. ${ }^{96}$ The synthesis of $\mathrm{Ni}_{2} \mathrm{P}-\mathrm{YS}$ involved a phosphorization process (at $300^{\circ} \mathrm{C}$ in $\mathrm{PH}_{3} / \mathrm{Ar}$ flow for $2 \mathrm{~h}$ ) of Ni-glycerate yolk-shell precursor prepared from nickel nitrate and glycerol. To further synthesize $\mathrm{S} @ \mathrm{Ni}_{2} \mathrm{P}-\mathrm{YS}, \mathrm{Ni}_{2} \mathrm{P}-\mathrm{YS}$ and sulfur were ground together and heated to $155^{\circ} \mathrm{C}$ for $24 \mathrm{~h}$, with a further heating step at $200^{\circ} \mathrm{C}$ under argon atmosphere for $30 \mathrm{~min}$. Therefore, a mesoporous host material with high conductivity and with a yolk-shell structure was obtained with $65 \mathrm{wt} \%$ sulfur content. According to the authors, this type of structure, as well as the chemical adsorption interaction between $\mathrm{Ni}_{2} \mathrm{P}$ and the polysulfides, facilitates the transport of both electrons and lithium ions and prevents the dissolution of the polysulfides in the electrolyte. At $0.2 \mathrm{C}$, an initial discharge capacity of $1409 \mathrm{~mA} \mathrm{~h} \mathrm{~g}^{-1}$ is reached, and $919 \mathrm{~mA} \mathrm{~h} \mathrm{~g}^{-1}$ remain after 100 cycles. Furthermore, the $\mathrm{Ni}_{2} \mathrm{P}$ does not contribute to the capacity in the working potential range (1.8-2.8 V) and also maintains its original phase by not reacting with sulfur, thus providing a stable structure.

A remarkable growth in the number of publications for materials that were reviewed in this section can be observed in recent years. New compounds with very promising characteristics have been proposed to improve the conductivity and stability of the electrode, improving the confinement of sulfur and polysulfides. Thus, the high conductivity of some materials such as nickel phosphide, metallic nickel, titanium carbide, titanium nitride allows used them as electron conducting matrix. The structures of these materials not only work as a host structure for sulfur and a conductive network, but also as active surfaces where interactions with sulfur and polysulfides are established through $\mathrm{Ni}-\mathrm{S}$, P-S and N-S bonds.

Although PAF and MOP have low conductivity, a good sulfur confinement within the porous structures was achieved. In other materials, such as hydroxides, metallic sulfides, prussian blue, it is important to highlight the presence of polar functional groups that give rise to the formation of bonds with sulfur and polysulfides. In addition, the complex cathode structures allow for physical sulfur and polysulfide encapsulation.

\section{Further Discussion}

It is important to consider the specific parameters involved in the synthesis process of the host material itself, and in its combination with sulfur, such as, temperature when working with any heat-treatment, or variation in sulfur-host material weight ratio. The morphology-structure of the host material used and the coating or mixing technique applied in order to combine it with elemental sulfur also influence the final electrochemical performance of the composite material, and therefore we have highlighted these issues in the presentation of materials above, and in the tables. It is still not yet clear if all the efforts made to manufacture nanostructured cathodes, with a high degree of complexity, both in their structure and in their production process, will be scalable to an industrial production level. Or whether most of this research will only remain only of academic interest. Any new battery technology should not only be competitive with current technology in terms of electrochemical performance, but also from an economics perspective. Although studies cited in Tables I-IV provide important knowledge of the systems, they continue below the commercial scale and cannot be massively produced. It is therefore also important, that the development of composite cathode materials rely on the use of both inexpensive raw materials and affordable synthetic processes. Finally, since batteries will naturally be mass-produced, it should be possible to envisage the scaling-up of the process. Unfortunately, while the inexpensive and abundant nature of elemental sulfur is always highlighted, pricing of host materials and the possibility of scaling up synthetic processes, are not always analyzed in work presented in Tables I-IV.

Tables I-IV show that to compensate the poor conductivity of sulfur and also, in some cases, of the cathode material, it is common to use an extra conductive agent within the composite cathode. Although great advances have been made in the development of new materials, both carbonaceous and non-carbonaceous, in most cases these aggregates are still necessary. There is a trade-off in the development of new materials, seeking to achieve both excellent electric conductors, as well as porous structures that may be able to contain large quantities of non-conductive sulfur in their hollows. These two objectives cannot be simultaneously accomplished. Both highly porous structures, and the addition of sulfur decrease the conductivity of any bulk material. Therefore, the addition of an additional highly conductive material is, most often, still necessary. However, a huge difference still exists in the addition of such extra conductors between carbonaceous and non-carbonaceous materials. In the first group, the typical percentage used is around $5 \%$ and very rarely exceeds $10 \%$. Whereas, in the case of non-carbonaceous materials, the minimum percentage usually employed is close to $10 \%$, with $20 \%$ being the most often employed amount (see Tables I-IV). 


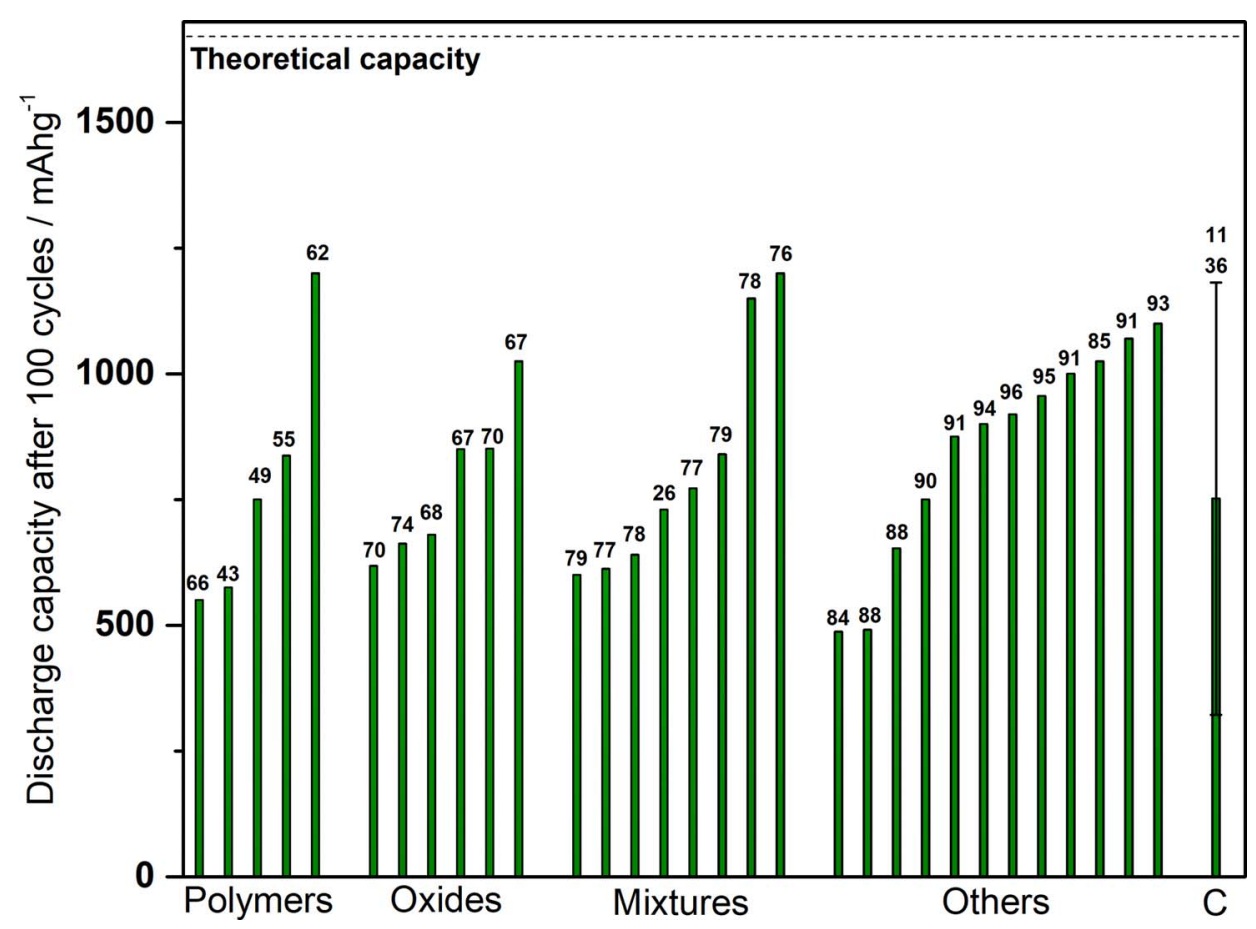

Figure 1. Summarized discharge capacity values after 100 cycles for represented compounds discussed in this review. Numbers above the bars correspond to reference numbers.
Figure 1 shows a comparison of discharge capacity values after 100 cycles for several of the non-carbonaceous materials presented in this work and some carbonaceous materials reported in two recent review articles. ${ }^{11,36}$ Only data for those materials for which at least 100 cycles have been reported, and for which discharge current values in between $0.1 \mathrm{C}$ and $0.5 \mathrm{C}$ were tested have been plotted. The first thing that should be noticed, is that all of the cathode materials reported show capacity values within the same range, regardless of the chemical nature of the material. A closer inspection to Figure 1 shows that no big variations are reported within the oxide's group (781 \pm 155 $\mathrm{mA} \mathrm{h}^{-1}$ ); while much larger differences exist within polymers' and ternary composites' groups $\left(782 \pm 262\right.$ and $818 \pm 235 \mathrm{~mA} \mathrm{~h} \mathrm{~g}^{-1}$, respectively). Curiously high capacity values were obtained when polyacrylonitrile was present in the cathode. Finally, a comprehensive evaluation of Tables I to IV show that no correlation between discharge capacity and sulfur loading.

Overall, Figure 1 shows that similar high capacity values could be obtained, using either carbonaceous or non-carbonaceous cathode materials. In addition, cyclability and even costs are similar for both. The built-up of advanced carbon cathodes from inexpensive raw materials usually requires a chemical treatment and high temperatures, which levels up costs with non-carbonaceous materials.

In addition, carbonaceous materials present at least one of the following disadvantages: they are synthesized from fossil-derived precursors, energy-intensive synthetic procedures, multistep synthesis route, accumulation of large amounts of waste products, and/or use of environmentally non-friendly reactants. ${ }^{37}$

Unfortunately, very few articles in the literature report on how new cathode materials, whether carbonaceous or non-carbonaceous, quantitatively counteract the shuttle effect. A reported improved cell performance could alternatively be attributed to cathode material, and/or membrane, and/or cell configuration. Most importantly, a new cathode material can contribute to a better cell performance by either trapping soluble sulfur species, and/or by an improved conductivity of the whole cathode. To the best of our knowledge, it is not possible to differentiate these two phenomena. Therefore, most often, it is difficult to quantify the polysulfides adsorption capacity of a given new material.

A large number of researchers, amongst them Borchardt et al., ${ }^{37}$ have proposed a standardization of all parameters of the electrochemical cells with the aim of achieving a more reliable and reasonable comparison between results published in the scientific literature. We could not agree more with this idea. The attentive reader will have noticed from results summarized in the previous sections, that different authors report remaining capacity values at different discharge rates, and for different number of cycles. A quick analysis of the literature on the field of lithium-sulfur cathodes, both carbonaceous and non-carbonaceous, shows something similar to a blind race toward the a battery with higher discharge capacity and higher capacity retention. In this wild race, many researchers seem to publish their best results exclusively. An external reader might wonder whether the sole objective of some reports is reaching a higher value than previous publications. If we all aim at pushing the field forward in a rational way, then we should all attempt to bring some physical and chemical understanding to experimental results, i.e. why some materials work better than others. In this context, it will be a great advantage to the field if authors will not only publish the optimal working conditions for their electrodes, but also results for standardized conditions, such as discharge/charge rate, discharge capacity and capacity retention at certain values, voltage window, a given electrolyte, sulfur loading, etc., so as to facilitate comparisons, and in order to make it possible to draw trends in electrochemical performance. Unfortunately, a thorough understanding of the redox mechanisms and processes in the different sulfur cathodes is still missing. It is in this context, that we also advocate for uniformity in result reporting, in conjunction with more in depth studies for the different newly proposed materials. Only with a rational understanding of the ongoing processes in the cathode, we will be able to overcome the non-negligible limitations of these cathodes.

\section{Conclusions}

Over the last years, many different cathode materials have been proposed. Composite materials are presented as an alternative to solve the problems of conductivity, loss of active material and volume changes that take place in conventional sulfur electrodes.

Within the sulfur-polymer category, a larger number of publications is found for polyaniline, polyacrylonitrile and polypyrrole. For several composites the structures can be well defined, while for others, they are instead characterized as amorphous materials. The best result for capacity retention was obtained for one of the sulfurpolyacrylonitrile composite materials with $1200 \mathrm{~mA} \mathrm{~h} \mathrm{~g}^{-1}$ at $0.5 \mathrm{C}$ 
after 100 cycles. In addition, the preparation of a composite electrode using sulfur-polyaniline, displaying urchine-like structure, as active material without the addition of any carbon conductive agent is highlighted. ${ }^{46}$

A shorter list of publications referring to the use of metal oxides as host materials has been reported. Most numerous are those sulfurmetal oxide materials that use either titanium oxide or manganese oxide. Almost all oxide synthesis procedures involve a calcination stage working at temperatures between $350-600^{\circ} \mathrm{C}$. An exception, is the synthesis of a sulfur-manganese dioxide material prepared from a chemical reaction in aqueous solution under ambient conditions. ${ }^{67}$

The polar nature of the oxides and their highly porous structure that provide both a physical confinement for the active material and a strong chemical interaction with polysulfides make these oxides attractive host materials.

The incorporation of small amounts of metal oxides to polymeric compounds has also been proposed. The idea is to add together the advantages of both compounds. Materials with ordered structures, such as core-shell, were recognized, with a sulfur content up to 60 wt $\%{ }^{78,79}$ Conversely, other materials with an agglomerated structure where the sulfur content was lower, about $40 \mathrm{wt} \%$ have also been reported. The best result was for the compound $\mathrm{S}-\mathrm{PAN}-\mathrm{Mg}_{0.6} \mathrm{Ni}_{0.4} \mathrm{O}$ with a capacity retention of $1200 \mathrm{~mA} \mathrm{~h} \mathrm{~g}{ }^{-1}$ after 100 cycles at 0.1 C. ${ }^{77}$ However, the sulfur content in this material is less than $50 \mathrm{wt} \%$, compromising the specific energy of the cathode as a whole. For the compound $\mathrm{S}-\mathrm{PPy}-\mathrm{TiO}_{2}$ with a sulfur content greater than $60 \mathrm{wt} \%$, a capacity retention of $1150 \mathrm{~mA} \mathrm{~h} \mathrm{~g}^{-1}$ after 100 cycles at $0.1 \mathrm{C}$ was achieved. ${ }^{78}$ In this case, it was not necessary to add a carbon conductive agent in the preparation of the electrode. ${ }^{78}$

In recent years, new types of compounds such as nitrides, carbides, sulfides, and compounds with organic and organo-metallic structures have been investigated as sulfur hosts. It is important to highlight results obtained for several of these compounds, which display capacity retention values in the order of $700 \mathrm{~mA} \mathrm{~h} \mathrm{~g}^{-1}$, even beyond 500 cycles. For the sulfur-MOP compound, fantastic cycling results were achieved: a capacity retention greater than $700 \mathrm{~mA} \mathrm{~h} \mathrm{~g}^{-1}$ after 1000 cycles at $0.2 \mathrm{C} .^{91} \mathrm{~S} / \mathrm{Ti}_{2} \mathrm{C}$ and $\mathrm{TiN}-\mathrm{S}$ have also shown impressive results. 86,90

In summary, we venture to say that non-carbonaceous materials are in an equal and fair competition, and withstand at this point very similar chances, as candidates to be incorporated in future commercial lithium-sulfur batteries, if compared with carbonaceous cathodes.

In our humble opinion, the large difference in the number of publications of carbonaceous vs. non-carbonaceous materials for lithiumsulfur batteries, is mainly due to the tradition in the use of carbon as inexpensive conductive supports. Tradition has in turn led to the development of a large library of knowledge that has been built over decades on the utilization of carbon in energy storage systems.

\section{Acknowledgments}

VF and AYT are CONICET Research Fellows. ANA acknowledges a CONICET doctoral fellowship. Funding from Agencia Nacional de Promoción Científica y Tecnológica, through PICT V-2014 3654 and FITR-INDUSTRIA 9/2013 are gratefully acknowledged.

\section{ORCID}

Victoria Flexer (iD https://orcid.org/0000-0002-4385-8846

\section{References}

1. Z. Li, Y. Huang, L. Yuan, Z. Hao, and Y. Huang, Carbon, 92, 41 (2015).

2. M. Wild, L. O'Neill, T. Zhang, R. Purkayastha, G. Minton, M. Marinescu, and G. J. Offer, Energy \& Environmental Science, 8(12), 3477 (2015).

3. A. Fotouhi, D. J. Auger, K. Propp, S. Longo, and M. Wild, Renewable and Sustainable Energy Reviews, 56, 1008 (2016).

4. M. G Buonomenna and J. Bae, Nanoscience \& Nanotechnology-Asia, 6(1), 28 (2016).

5. Q. Pang, X. Liang, C. Y. Kwok, and L. F. Nazar, Journal of The Electrochemical Society, 162(14), A2567 (2015).
6. L. C. Zeng, W. H. Li, Y. Jiang, and Y. Yu, Rare Metals, 36(5), 339 (2017)

7. L. Ma, K. E. Hendrickson, S. Wei, and L. A. Archer, Nano Today, 10(3), 315 (2015).

8. G. Xu, B. Ding, J. Pan, P. Nie, L. Shen, and X. Zhang, Journal of Materials Chemistry A, 2(32), 12662 (2014).

9. L. F. Nazar, M. Cuisinier, and Q. Pang, MRS Bulletin, 39(5), 436 (2014).

10. H. Danuta and U. Juliusz, Electric dry cells and storage batteries US Patent 3043896 A, 1962.

11. A. Manthiram, S.-H. Chung, and C. Zu, Advanced Materials, 27(12), 1980 (2015).

12. H. Cheng and S. Wang, Journal of Materials Chemistry A, 2(34), 13783 (2014).

13. X. Shen, H. Liu, X.-B. Cheng, C. Yan, and J.-Q. Huang, Energy Storage Materials, 12, 161 (2018).

14. A. F. Hofmann, D. N. Fronczek, and W. G. Bessler, Journal of Power Sources, 259, 300 (2014).

15. M. Gu, J. Lee, Y. Kim, J. S. Kim, B. Y. Jang, K. T. Lee, and B.-S. Kim, RSCAdvances, 4(87), 46940 (2014).

16. A. Manthiram, Y. Fu, S.-H. Chung, C. Zu, and Y.-S. Su, Chemical Reviews, 114(23), 11751 (2014)

17. L. E. Camacho-Forero, T. W. Smith, S. Bertolini, and P. B. Balbuena, The Journal of Physical Chemistry C, 119(48), 26828 (2015).

18. D. Lin, Y. Liu, and Y. Cui, Nat Nano, 12(3), 194 (2017).

19. L. Chen and L. L. Shaw, Journal of Power Sources, 267, 770 (2014).

20. P. G. Bruce, S. A. Freunberger, L. J. Hardwick, and J.-M. Tarascon, Nat Mater, 11(1), 19 (2012).

21. X. Fang and H. Peng, Small, 11(13), 1488 (2015).

22. S. Zhang, K. Ueno, K. Dokko, and M. Watanabe, Advanced Energy Materials, 5(16), (2015).

23. S. S. Zhang, Journal of Power Sources, 231, 153 (2013).

24. Y. X. Yin, S. Xin, Y. G. Guo, and L. J. Wan, Angewandte Chemie - International Edition, 52(50), 13186 (2013).

25. Y. S. Su and A. Manthiram, Journal of Power Sources, 270, 101 (2014).

26. J. Xu, B. Jin, H. Li, and Q. Jiang, International Journal of Hydrogen Energy, 42(32), 20749 (2017).

27. Z. Li, Y. Huang, L. Yuan, Z. Hao, and Y. Huang, Carbon, 92, 41 (2015).

28. Z. Li, Y. Jiang, L. Yuan, Z. Yi, C. Wu, Y. Liu, P. Strasser, and Y. Huang, ACS Nano, 8(9), 9295 (2014).

29. G. Zhou, D.-W. Wang, F. Li, P.-X. Hou, L. Yin, C. Liu, G. Q. Lu, I. R. Gentle, and H.-M. Cheng, Energy \& Environmental Science, 5(10), 8901 (2012).

30. Y. Wu, M. Gao, X. Li, Y. Liu, and H. Pan, Journal of Alloys and Compounds, 608 , 220 (2014).

31. M. S. Park, J. S. Yu, K. J. Kim, G. Jeong, J. H. Kim, T. Yim, Y. N. Jo, U. Hwang, S. Kang, T. Woo, H. Kim, and Y. J. Kim, RSC Advances, 3(29), 11774 (2013).

32. M. Yu, R. Li, M. Wu, and G. Shi, Energy Storage Materials, 1, 51 (2015).

33. S. Wu, R. Ge, M. Lu, R. Xu, and Z. Zhang, Nano Energy, 15, 379 (2015).

34. Z. Du, J. Xu, S. Jin, Y. Shi, C. Guo, X. Kong, Y. Zhu, and H. Ji, Journal of Power Sources, 341, 139 (2017).

35. J. Liang, Z.-H. Sun, F. Li, and H.-M. Cheng, Energy Storage Materials, 2, 76 (2016).

36. X. Gu, L. Hencz, and S. Zhang, Batteries, 2(4), 33 (2016).

37. L. Borchardt, M. Oschatz, and S. Kaskel, Chemistry - A European Journal, 22(22), 7324 (2016).

38. G. Xu, B. Ding, P. Nie, L. Shen, J. Wang, and X. Zhang, Chemistry - A European Journal, 19(37), 12306 (2013).

39. Q. Pang, J. Tang, H. Huang, X. Liang, C. Hart, K. C. Tam, and L. F. Nazar, Advanced Materials, 27(39), 6021 (2015).

40. P. T. Dirlam, R. S. Glass, K. Char, and J. Pyun, Journal of Polymer Science, Part A: Polymer Chemistry, 55(10), 1635 (2017).

41. X. Liu, J. Q. Huang, Q. Zhang, and L. Mai, Advanced Materials, 29(20), (2017).

42. Y. Fu and A. Manthiram, Journal of Physical Chemistry C, 116(16), 8910 (2012).

43. Y. An, P. Wei, M. Fan, D. Chen, H. Chen, Q. Ju, G. Tian, and K. Shu, Applied Surface Science, 375, 215 (2016).

44. B. Zhang, S. Wang, M. Xiao, D. Han, S. Song, G. Chen, and Y. Meng, RSC Advances, 5(48), 38792 (2015).

45. T. N. L. Doan, M. Ghaznavi, A. Konarov, Y. Zhang, and P. Chen, Journal of Solid State Electrochemistry, 18(1), 69 (2014).

46. Q. Lu, H. Gao, Y. Yao, N. Liu, X. Wang, and F. Wang, RSC Advances, 5(113), 92918 (2015).

47. G. Yuan and H. Wang, Journal of Energy Chemistry, 23(5), 657 (2014).

48. Y. Zhang, Y. Zhao, A. Konarov, D. Gosselink, Z. Li, M. Ghaznavi, and P. Chen, Journal of Nanoparticle Research, 15(10), (2013).

49. Y. Xie, H. Zhao, H. Cheng, C. Hu, W. Fang, J. Fang, J. Xu, and Z. Chen, Applied Energy, 175, 522 (2016).

50. Y. Zhang, Z. Bakenov, Y. Zhao, A. Konarov, T. N. L. Doan, M. Malik, T. Paron, and P. Chen, Journal of Power Sources, 208, 1 (2012).

51. Y. Fu, Y. S. Su, and A. Manthiram, Journal of the Electrochemical Society, 159(9), A1420 (2012)

52. Y. Fu and A. Manthiram, RSC Advances, 2(14), 5927 (2012).

53. L. Duan, J. Lu, W. Liu, P. Huang, W. Wang, and Z. Liu, Colloids and Surfaces A: Physicochemical and Engineering Aspects, 414, 98 (2012).

54. H. Gao, Q. Lu, N. Liu, X. Wang, and F. Wang, Journal of Materials Chemistry A, 3(14), 7215 (2015).

55. L. Xiao, Y. Cao, J. Xiao, B. Schwenzer, M. H. Engelhard, L. V. Saraf, Z. Nie, G. J. Exarhos, and J. Liu, Advanced Materials, 24(9), 1176 (2012).

56. J. Hyun, P. C. Lee, M. J. Jung, and T. Ishihara, Electrochemistry, 84(11), 836 (2016).

57. F. Wu, J. Chen, R. Chen, S. Wu, L. Li, S. Chen, and T. Zhao, Journal of Physical Chemistry C, 115(13), 6057 (2011).

58. J. Wang, J. Yang, J. Xie, and N. Xu, Advanced Materials, 14(13-14), 963 (2002)

59. S. Zhang, Energies, 7(7), 4588 (2014). 
60. L. Wang, X. He, J. Li, J. Gao, J. Guo, C. Jiang, and C. Wan, Journal of Materials Chemistry, 22(41), 22077 (2012)

61. T. N. L. Doan, M. Ghaznavi, Y. Zhao, Y. Zhang, A. Konarov, M. Sadhu, R. Tangirala, and P. Chen, Journal of Power Sources, 241, 61 (2013).

62. Y. Zhang, Y. Zhao, Z. Bakenov, A. Konarov, and P. Chen, Journal of Power Sources, 270, 326 (2014).

63. G. Zhu, World Electric Vehicle Journal, 4(1), 332 (2011).

64. Y. Li, Q. Zeng, I. R. Gentle, and D. W. Wang, Journal of Materials Chemistry A, 5(11), 5460 (2017).

65. D. Han, B. Zhang, M. Xiao, P. Shen, S. Wang, G. Chen, and Y. Meng, International Journal of Hydrogen Energy, 39(28), 16067 (2014).

66. A. Hoefling, Y. J. Lee, and P. Theato, Macromolecular Chemistry and Physics, 218(1), (2017).

67. X. Liang and L. F. Nazar, ACS Nano, 10(4), 4192 (2016).

68. Q. Li, Z. Zhang, K. Zhang, L. Xu, J. Fang, Y. Lai, and J. Li, Journal of Solid State Electrochemistry, 17(11), 2959 (2013).

69. X. Z. Ma, B. Jin, H. Y. Wang, J. Z. Hou, X. B. Zhong, H. H. Wang, and P. M. Xin, Journal of Electroanalytical Chemistry, 736, 127 (2015).

70. K. Xie, Y. Han, W. Wei, H. Yu, C. Zhang, J. G. Wang, W. Lu, and B. Wei, RSC Advances, 5(94), 77348 (2015)

71. S. Wang, Z. Yang, H. Zhang, H. Tan, J. Yu, and J. Wu, Electrochimica Acta, 106, 307 (2013).

72. H. Cheng, S. Wang, D. Tao, and M. Wang, Functional Materials Letters, 7(3), (2014)

73. X. C. Gao, Y. J. Shen, L. L. Xing, Q. Wang, and X. Y. Xue, Materials Letters, 183 , 413 (2016)

74. X. Liang, Q. Song, Y. Liu, and H. Liu, International Journal of Electrochemical Science, 10(11), 9333 (2015).

75. Y. Hou, J. Xiao, Y. Guo, M. Qi, A. Jiang, and Y. Li, Journal of Materials Science: Materials in Electronics, 28(12), 8901 (2017).

76. Y. Zhang, Y. Zhao, A. Yermukhambetova, Z. Bakenov, and P. Chen, Journal of Materials Chemistry A, 1(2), 295 (2013).

77. A. Yermukhambetova, Z. Bakenov, Y. Zhang, J. A. Darr, D. J. L. Brett, and P. R. Shearing, Journal of Electroanalytical Chemistry, 780, 407 (2016)

78. Y. Zhao, W. Zhu, G. Z. Chen, and E. J. Cairns, Journal of Power Sources, 327, 447 (2016).

79. M. Yan, Y. Zhang, Y. Li, Y. Huo, Y. Yu, C. Wang, J. Jin, L. Chen, T. Hasan, B. Wang, and B. L. Su, Journal of Materials Chemistry A, 4(24), 9403 (2016).
80. J. D. Liu, S. Q. Zhang, S. B. Yang, Z. F. Shi, S. T. Zhang, and L. K. Wu, Ionics, 19(11), 1477 (2013).

81. B. Guo, T. Ben, Z. Bi, G. M. Veith, X. G. Sun, S. Qiu, and S. Dai, Chemical Communications, 49(43), 4905 (2013).

82. R. Demir-Cakan, M. Morcrette, F. Nouar, C. Davoisne, T. Devic, D. Gonbeau, R. Dominko, C. Serre, G. Férey, and J.-M. Tarascon, Journal of the American Chemical Society, 133(40), 16154 (2011).

83. S.-H. Chung and A. Manthiram, Electrochimica Acta, 107(Supplement C), 569 (2013).

84. X. Gao, Y. Wang, Z. Ma, W. Jiang, Y. Zou, and C. Lu, Journal of Materials Science, 51(11), 5139 (2016).

85. P. T. Dirlam, J. Park, A. G. Simmonds, K. Domanik, C. B. Arrington, J. L. Schaefer, V. P. Oleshko, T. S. Kleine, K. Char, R. S. Glass, C. L. Soles, C. Kim, N. Pinna, Y. E. Sung, and J. Pyun, ACS Applied Materials and Interfaces, 8(21), 13437 (2016).

86. X. Liang, A. Garsuch, and L. F. Nazar, Angewandte Chemie - International Edition, 54(13), 3907 (2015)

87. J. X. Zhang, Z. S. Ma, J. J. Cheng, Y. Wang, C. Wu, Y. Pan, and C. Lu, Journal of Electroanalytical Chemistry, 738, 184 (2015).

88. J. Zhang, H. Hu, Z. Li, and X. W. Lou, Angewandte Chemie - International Edition, 55(12), 3982 (2016).

89. Q. Wang and D. O'Hare, Chemical Reviews, 112(7), 4124 (2012).

90. Z. Cui, C. Zu, W. Zhou, A. Manthiram, and J. B. Goodenough, Advanced Materials, 6926 (2016).

91. L. Bai, D. Chao, P. Xing, L. J. Tou, Z. Chen, A. Jana, Z. X. Shen, and Y. Zhao, ACS Applied Materials and Interfaces, 8(23), 14328 (2016).

92. D. Su, M. Cortie, H. Fan, and G. Wang, Advanced Materials, (2017)

93. D. R. Deng, F. Xue, Y. J. Jia, J. C. Ye, C. D. Bai, M. S. Zheng, and Q. F. Dong, ACS Nano, 11(6), 6031 (2017).

94. X. Zhu, J. Tian, X. Liu, W. Huang, D. Luo, Z. Wang, and Z. Shan, RSC Advances, 7(56), 35482 (2017).

95. W. Tang, Z. Chen, B. Tian, H.-W. Lee, X. Zhao, X. Fan, Y. Fan, K. Leng, C. Peng, M.-H. Kim, M. Li, M. Lin, J. Su, J. Chen, H. Y. Jeong, X. Yin, Q. Zhang, W. Zhou, K. P. Loh, and G. W. Zheng, Journal of the American Chemical Society, 139(29), 10133 (2017).

96. J. Cheng, D. Zhao, L. Fan, X. Wu, M. Wang, N. Zhang, and K. Sun, Journal of Materials Chemistry A, 5(28), 14519 (2017). 